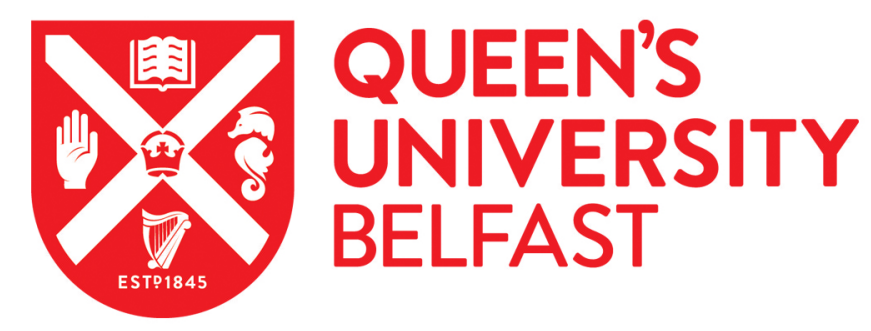

\title{
Sugarcane bagasse based biorefineries in India: potential and challenges
}

Konde, K. S., Nagarajan, S., Kumar, V., Patil, S. V., \& Ranade, V. V. (2021). Sugarcane bagasse based biorefineries in India: potential and challenges. Sustainable Energy and Fuels, 5(1), 52-78.

https://doi.org/10.1039/d0se01332c

\section{Published in:}

Sustainable Energy and Fuels

\section{Document Version:}

Peer reviewed version

Queen's University Belfast - Research Portal:

Link to publication record in Queen's University Belfast Research Portal

\section{Publisher rights}

Copyright 2020, The Royal Society of Chemistry.

This work is made available online in accordance with the publisher's policies. Please refer to any applicable terms of use of the publisher.

\section{General rights}

Copyright for the publications made accessible via the Queen's University Belfast Research Portal is retained by the author(s) and / or other copyright owners and it is a condition of accessing these publications that users recognise and abide by the legal requirements associated with these rights.

Take down policy

The Research Portal is Queen's institutional repository that provides access to Queen's research output. Every effort has been made to ensure that content in the Research Portal does not infringe any person's rights, or applicable UK laws. If you discover content in the Research Portal that you believe breaches copyright or violates any law, please contact openaccess@qub.ac.uk. 


\title{
Sugarcane Bagasse based Biorefineries in India: Potential and Challenges
}

Received 00th January 20xx, Accepted 00th January 20xx DOI: $10.1039 / x 0 x \times 00000 x$

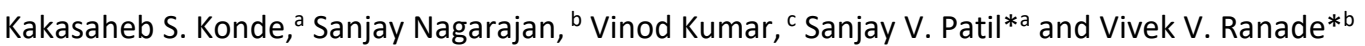

Sugarcane bagasse (SCB) is one of the world's most abundant agricultural residues and in an Indian context, 100 million tonnes per annum is produced. Current use of SCB is restricted to cogeneration of steam and power, however considering its potential, cogeneration is not the best valorisation route. Furthermore, with falling electricity prices and reducing global sugar prices due to excess sugar stocks, it is inevitable that the waste generated (SCB) by the sugar mills are utilised for generating revenue sustainably. With this background, this review aims to put forth a biorefinery perspective based on SCB feedstock. Biogas and bioethanol are Government of India's current focus with policies and subsidies clearly pointing towards a sizeable future market. Therefore, alongside these biofuels, high-value chemicals such as xylitol, succinic acid and lactic acid were identified as other desired products for the biorefinery. This review firstly discusses SCB pre-treatment options based on end applications (saccharification or anaerobic digestion, AD). Next, state-of-art for each of these aspects were reviewed and our perspective for a profitable biorefinery is presented. We propose an AD based biorefinery where vortex-based hydrodynamic cavitation was found to be the best choice for pre-treatment. AD is not only considered a bioprocess for energy production here but also a 'pre-treatment', where partial conversion of holocellulose leads to a digestate rich in loosened fibre matrix. This digestate rich in cellulose can be enzymatically hydrolysed and further valorised biochemically. This approach would be cost effective and provide sustainable waste management route for the sugar mills.
\end{abstract}

\section{Introduction}

Sugarcane is a rich source of sucrose $(\sim 10 \%)$ and accounts for approximately $80 \%$ of the global sugar production. India is one of the leading sugarcane (and sugar) producing countries in the world. Indian sugar industry has witnessed tremendous growth in the past 60 years without any impediments. As a result, the area under sugarcane cultivation and sugar production have been continuously increasing over the last six decades. India currently ranks second in cultivation area (5.11 million ha) and sugarcane production (303.83 million tonnes) next to Brazil. Since 1930-31, the number of sugar mills in operation in India increased from 29 to 520 , thereby leading to an increase in sugar production from 0.12 million to 32.82 million tonnes per year in 2018-19 1. Today, Indian sugar industry's annual output is worth approximately ₹ 800 billion ( $\sim 12.5$ billion). With this impeccable net worth, the sugar industry plays an important role in the socio-economic development of India by contributing to rural infrastructure like roads, educational, medical, access to finance, other facilities, etc. Indian sugar industry being the second largest agro-based industry after cotton, plays a vital

a. Department of Alcohol Technology and Biofuels, Vasantdada Sugar Institute, Manjari (Bk.), Pune, 412307, India.

b. School of Chemistry and Chemical Engineering, Queen's University of Belfast, Stranmillis Road, Belfast BT95AG, United Kingdom.

School of Water, Energy and Environment, Cranfield University, Cranfield, MK43 $O A L$, United Kingdom.

*Authors to whom correspondence may be addressed: sv.patil@vsisugar.org.in; v.ranade@qub.ac.uk role in the rural livelihood of $\sim 60$ million sugarcane farmers and $\sim 0.5$ million workers directly employed in sugar mills. Employment is also generated in various ancillary activities relating to transportation, trade servicing of machinery and supply of agriculture inputs.

While this increased the overall wellbeing of sugarcane farmers, the growth of sugarcane industry also led to associated waste related issues. The major solid waste streams generated in the sugar manufacturing process include sugarcane trash, sugarcane bagasse (SCB), press mud cake (PMC) and SCB fly ash (Figure 1). The key characteristics of these solid wastes are summarized in Table 1. Although cogeneration for steam and electricity production is the most harnessed industrial route for SCB valorisation ${ }^{2}$, high value co-product and biofuel production from SCB and other wastes have also been explored ${ }^{3}$. For example, SCB is also used as a raw material in agro-residue based pulp and paper mills. Other SCB based products with added value are furfural and animal feed. Another example is PMC that is rich in organic content, phosphate, calcium and magnesium and therefore is used as fertilizer after biocomposting with biomethanated spent wash (distillery wastewater). Attempts have been made to utilise PMC as fuel in sugar mills either alone or in combination with $\mathrm{SCB}$, however it leads to the generation of $25 \%$ more ash than SCB 4 . Sugarcane trash is conventionally disposed by burning in the fields. SCB fly ash is typically disposed in pits, however it is also applied on land for soil amendment in some areas or used for brick manufacturing. In addition to the solid wastes generated 
during sugar production, a significant portion of mother liquor left behind after crystallisation of sugars from juice ends up as a liquid waste - molasses ( $4 \%$ of sugarcane crushed). Molasses is typically used to produce ethanol via fermentation. Many sugar mills also run distilleries as their subsidiaries for producing fuel ethanol and extra neutral alcohol to maximise profit margins. The additional profits become critical especially because, in the recent years, due to the excess production of sugarcane, the sugar inventory has been piling up in India leading to a crisis. In addition, due to decreasing international prices of sugar, paying fair and remunerative price (FRP) to the farmers has also become a challenge. In view of the sugar crises, the Government of India (Gol) took a policy decision to implement the ethanol blending programme (EBP) and to go for $10 \%$ blending (in petrol) throughout the country and cut oil imports ( $20 \%$ by 2030 ). Furthermore, to increase profits with molasses based ethanol, efficient waste management is required to valorise the waste streams into value added products.
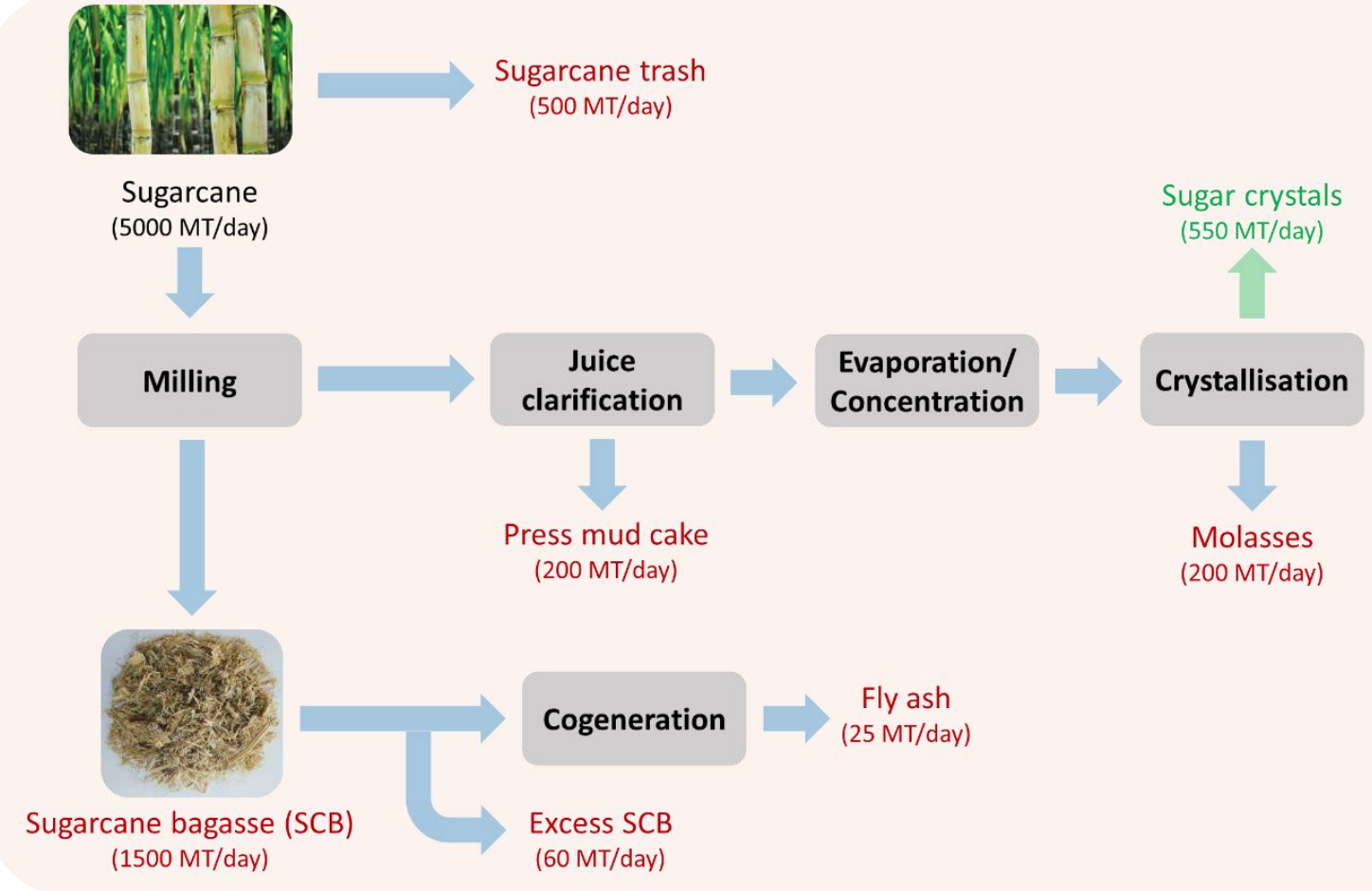

Fly ash

(25 MT/day)

Figure 1: Process flow diagram for different waste streams generated by sugar industries.

Amongst the waste generated by the sugar industry, SCB contributes to a significant proportion ( $\sim 100$ million tonnes per annum). It is also one of the largest agriculture residues in the world ${ }^{5-7}$. This waste does not just present a challenge, but also creates an opportunity where proper waste resource management can lead to additional revenue. This revenue will help in tackling the problems faced by the Indian sugar industry such as the falling sugar prices, surplus sugar production and payment of FRP. A preliminary review of literature indicates that SCB can serve as potential feedstock for low cost production of green chemicals and fuels. This is mainly attributed to its abundant availability making its supply constant and stable.

The current SCB utilization approach in India is restricted to cogeneration (of steam \& power). Considering the valorisation potential of SCB, cogeneration is not the best option (although mature). There is limitation on use of SCB for cogeneration due to the diminishing market price of electricity. There will be a high demand for ethanol [> 9 billion litres by $2030{ }^{8}$ ] with excellent differential pricing offered by the Gol based on use of different intermediates/by-products of sugarcane processing. In future, economics of sugar industry will not only depend on sugar, ethanol or cogeneration but will also depend on optimal use of (wastes) resources available within the sugar industry. Meghana and Shastri's recent review on the global sugar industry with a strong focus on environmental impacts suggested that monetising the environmental impacts will also act as a driver towards utilising these wastes as resources 2 . This paradigm shift into waste-based biorefineries with a circular economy approach is therefore the way forward for the Indian sugar industries. 
Table 1: Characteristics of solid wastes generated in sugar mills

\begin{tabular}{|c|c|c|c|c|}
\hline $\begin{array}{l}\text { Solid } \\
\text { waste }\end{array}$ & Description & $\begin{array}{l}\text { Fraction of } \\
\text { sugarcane plant }\end{array}$ & Composition & References \\
\hline $\begin{array}{l}\text { Sugarcane } \\
\text { trash }\end{array}$ & $\begin{array}{l}\text { Leaves and tops } \\
\text { obtained upon } \\
\text { sugarcane } \\
\text { harvesting }\end{array}$ & $8-10 \%$ & $\begin{array}{l}40-44 \% \text { cellulose, } \\
30-33 \% \text { hemicellulose, } \\
17-22 \% \text { lignin, } \\
4-5 \% \text { ash }\end{array}$ & $\begin{array}{l}\text { Bhardwaj et al., 2019; } \\
\text { Franco et al., 2013; } \\
\text { Singh et al., 20089-11 }\end{array}$ \\
\hline $\begin{array}{l}\text { Sugarcane } \\
\text { bagasse }\end{array}$ & $\begin{array}{l}\text { Dry fibrous } \\
\text { residue obtained } \\
\text { after sugarcane } \\
\text { crushing and juice } \\
\text { extraction }\end{array}$ & $30 \%$ & $\begin{array}{l}40-50 \% \text { cellulose, } \\
19-25 \% \text { hemicellulose, } \\
17-25 \% \text { lignin, } \\
2-4 \% \text { ash }\end{array}$ & $\begin{array}{l}\text { Abhilash \& Singh, 2008; } \\
\text { Ezhumalai \& Thangavelu, } \\
\text { 2010; } \\
\text { Ingle et al., 201712-14 }\end{array}$ \\
\hline $\begin{array}{l}\text { Press } \\
\text { mud cake }\end{array}$ & $\begin{array}{l}\text { Solid residue } \\
\text { obtained upon } \\
\text { sugarcane juice } \\
\text { clarification }\end{array}$ & $4 \%$ & $\begin{array}{l}5-14 \% \text { crude wax, } \\
15-30 \% \text { fibre, } \\
5-15 \% \text { crude protein, } \\
5-15 \% \text { sugar, } \\
4-10 \% \mathrm{SiO}, \\
1-4 \% \mathrm{CaO} \\
1-3 \% \mathrm{PO} \\
0.5-1.5 \% \mathrm{MgO}, \\
9-10 \% \text { ash } \\
\end{array}$ & Velmurugan \& Partha, $2006^{15}$ \\
\hline $\begin{array}{l}\text { Sugarcane } \\
\text { bagasse } \\
\text { fly ash }\end{array}$ & $\begin{array}{l}\text { Generated after } \\
\text { the combustion } \\
\text { of SCB }\end{array}$ & $\begin{array}{l}0.005-0.066 \text { tons fly } \\
\text { ash/ton SCB } \\
\text { crushed }\end{array}$ & $65 \% \mathrm{SiO}_{2}$ and other metal oxides & $\begin{array}{l}\text { Umamaheswaran \& Batra, } \\
2008^{16}\end{array}$ \\
\hline
\end{tabular}

With this background, this review aims to examine innovative value-added products in addition to fuels that can be obtained from the transformation of SCB in an Indian context. Such initiatives towards a biorefinery, are expected to promote alternative approaches to steam and power. This work presents the state-of-the-art in this field especially focusing on high value products. The manuscript is structured in a way to first describe the potential of SCB as a feedstock for biorefineries, followed by the importance of pre-treatment in enhancing product yields. Finally, routes and processes for gaseous and liquid products, reported yields and challenges in adopting these SCB valorisation solutions into a biorefinery are highlighted.

\section{Sugarcane bagasse (SCB) and its potential as feedstock for biorefineries}

SCB is a lignocellulosic biomass that contains cellulose, hemicellulose and lignin which together forms a complex and recalcitrant structure. Cellulose is a linear homopolymer of glucose while hemicellulose is heteropolymer containing variety of hexose and pentose sugars and sugar acids. The sugars present in hemicellulosic fractions are typically glucose, galactose, mannose, arabinose and xylose with xylose being the most abundant sugar ( 90\%). Thus, cellulose and hemicellulose present in SCB are sources of fermentable sugars. The final fermentable sugar concentration in hydrolysate depends on cellulosic and hemicellulosic content (Table 1). The composition of SCB also affects its combustion characteristics and energy yield. The proximate and ultimate analysis of SCB as reported in literature are summarised in Table 2 . The fixed carbon was found to be in the range of $75.8 \%$ to $85.5 \%$, volatile matter varied between $11 \%$ to $20 \%$ and the ash content varied between $2 \%$ to $5 \%$. The data indicates that composition of bagasse varies depending on its source and sugar processing. The average gross calorific values (GCV) of SCB was found to be $3990 \mathrm{kcal} / \mathrm{kg}$ and is comparable to that of lignite coal and wood. Therefore, a significant quantity of bagasse is typically used in biomass boilers.

In the crushing season 2018-19, sugarcane crushing, sugar and SCB production was 303.83 million tonnes, $\mathbf{3 2 . 8 2}$ million tonnes and 91.15 million tonnes in India respectively ${ }^{1}$. SCB cogeneration in India picked up pace after the 'National programme on promotion of biomass power/bagasse-based cogeneration' was implemented by the Gol in 1992. As it leads to environmental and economic sustainability, the Gol formulated many promotional policies for setting up more combined heat and power (CHP) plants, which further encouraged such sugar plants to adopt cogeneration technology ${ }^{17}$. During the last two decades, many sugar mills have installed co-generation (power/steam) plants from 10 $\mathrm{MW} / \mathrm{hr}$ to above $50 \mathrm{MW} / \mathrm{hr}$ capacities. It helped in earning additional revenue and allowed sugar mills to pay higher cane price to farmers. The current total installed capacity of these cogeneration plants in India is $9200 \mathrm{MW}$. Despite its use in boilers, significant amount of SCB still remains as waste. As mentioned previously, the SCB based cogeneration electricity prices are going down, as cheap electricity is now available from other sources. Therefore, there is a need to identify other valorisation routes that can help in effective SCB management with a surplus economic gain. 


\section{ARTICLE}

Table 2: Proximate, ultimate analysis \& gross calorific value (GCV) of SCB

\begin{tabular}{|c|c|c|c|c|c|c|c|c|c|c|}
\hline \multicolumn{3}{|c|}{ Proximate analysis (\%) on dry basis } & \multirow{2}{*}{\multicolumn{6}{|c|}{ Elemental Analysis (\%) }} & \multirow{3}{*}{$\begin{array}{l}\text { GCV } \\
\text { (kcal/Kg) }\end{array}$} & \multirow{3}{*}{ References } \\
\hline \multirow{2}{*}{$\begin{array}{l}\text { Fixed } \\
\text { Carbon }\end{array}$} & \multirow{2}{*}{$\begin{array}{l}\text { Volatile } \\
\text { Matter }\end{array}$} & \multirow{2}{*}{ Ash } & & & & & & & & \\
\hline & & & C & $\mathbf{H}$ & $\mathbf{N}$ & $\mathbf{S}$ & $\mathbf{C l}$ & $\mathbf{0}$ & & \\
\hline 20.01 & 75.85 & 4.14 & $\begin{array}{l}48.6 \\
7 \\
\end{array}$ & 6.70 & 0.45 & 0.08 & - & $\begin{array}{l}44.1 \\
0 \\
\end{array}$ & 4014.2 & Islam et al., $2010^{18}$ \\
\hline 18.00 & 79.90 & 2.20 & $\begin{array}{l}44.6 \\
0\end{array}$ & 5.80 & 0.60 & 0.10 & 0.00 & $\begin{array}{l}44.5 \\
0\end{array}$ & 4322.3 & Leal et al., $2013^{19}$ \\
\hline 11.26 & 84.50 & 4.24 & $\begin{array}{l}38.8 \\
4 \\
\end{array}$ & 6.85 & 0.02 & 0.39 & - & $\begin{array}{l}53.9 \\
0 \\
\end{array}$ & 4124.1 & Gonçalves et al., $2017^{20}$ \\
\hline 12.39 & 85.49 & 2.12 & $\begin{array}{l}49.8 \\
4 \\
\end{array}$ & 6.00 & 0.20 & 0.06 & - & $\begin{array}{l}43.9 \\
0 \\
\end{array}$ & - & Kumar et al., $2017^{21}$ \\
\hline 13.05 & 84.41 & 2.45 & $\begin{array}{l}49.2 \\
0\end{array}$ & 4.70 & 0.20 & 0.04 & 0.16 & $\begin{array}{l}43.0 \\
0\end{array}$ & 3558.9 & Shukla \& Kumar, $2017^{22}$ \\
\hline 11.95 & 84.78 & 3.28 & $\begin{array}{l}44.8 \\
6 \\
\end{array}$ & 5.87 & 0.24 & 0.06 & - & $\begin{array}{l}48.9 \\
7 \\
\end{array}$ & 4298.4 & Varma \& Mondal, $2017^{23}$ \\
\hline 14.84 & 82.42 & 2.75 & $\begin{array}{l}41.9 \\
0 \\
\end{array}$ & 5.50 & 0.29 & 0.01 & - & $\begin{array}{l}52.2 \\
0 \\
\end{array}$ & - & $\begin{array}{l}\text { Ghorbannezhad et al., } \\
2018^{24}\end{array}$ \\
\hline 16.09 & 79.09 & 4.90 & 32.5 & 5.01 & 0.38 & 0.56 & - & $\begin{array}{l}61.5 \\
5 \\
\end{array}$ & 3948.2 & Kanwal et al., $2019^{25}$ \\
\hline 14.26 & 83.46 & 2.17 & $\begin{array}{l}46.3 \\
7 \\
\end{array}$ & 6.29 & 0.55 & 0.11 & - & $\begin{array}{l}46.7 \\
9\end{array}$ & 3422.7 & Manatura, $2020^{26}$ \\
\hline
\end{tabular}

In the present scenario, production of chemicals is completely reliant on fossil fuels which is non-sustainable and having a negative impact on the environment. As a result, there is a growing demand on clean, greener and sustainable technologies to manufacture fuels and chemicals that requires paradigm shift from petrochemical based synthesis towards bio-based production ${ }^{27}$. The main bottleneck in commercial success of biorefineries is high cost which stem from feedstocks and their pre-treatment. The profitable biorefineries could be realized by making use of waste streams rich in renewable carbon and substantially reduce the production cost and spare the edible feed stocks ${ }^{28}$. As mentioned earlier, India being the second largest producer of sugarcane crop in the world, generates massive amounts of SCB as waste. SCB is an inexpensive source of fermentable sugars and potential feedstock for second-generation biorefineries. It provides a significant opportunity for biofuels/biochemical/chemical industries in India as well as potential for rural economy development. Being a lignocellulosic feedstock with low nutritional value, the use of SCB precludes concerns about the food vs fuel debate, especially in country like India with a huge population. The current use of SCB for power generation or CHP is a low grade application and does not utilize its full potential. The annexation of second generation (2G) biorefinery into existing sugar mill through more efficient use of waste streams such as SCB will lead to revitalisation and sustainability of sugar industries 28,29 .

In 2017, Gol announced a call, in association with UK on "Industrial Waste Challenge" to find green and sustainable solutions for waste streams generated by five major industries in India and sugar mills were one of them. Our consortium ( $v W a$ ) was funded under this call and we proposed valorisation of SCB to five products of huge commercial value: bioCNG, xylitol, n-butanol, lactic and succinic acid and are working towards it. Potential products from SCB and their theoretical yields are listed Table 3 . The key challenges in valorisation of SCB via biochemical route are: development of a cost-effective pre-treatment method to render the biomass amenable to further biotransformation, simple \& cost effective detoxification, effective hydrolysis (without or in house low cost enzymes) and biotransformation of sugar in hydrolysates to the desired products which meet customer specifications without compromising safety, environment and economics.

Table 3: Theoretical yields of different commercial products on glucose, xylose and different components of SCB *

\begin{tabular}{|l|l|l|l|l|l|}
\hline Product** & Glucose & Xylose & Cellulose & Hemicellulose & SCB* \\
\hline Biogas $\left(\mathrm{m}^{3} / \mathrm{kg}\right)$ & 0.37 & 0.37 & 0.41 & 0.42 & 0.44 \\
\hline
\end{tabular}




\begin{tabular}{|l|l|l|l|l|l|}
\hline Ethanol $(\mathrm{kg} / \mathrm{kg})$ & 0.51 & 0.51 & 0.57 & 0.58 & 0.42 \\
\hline $\mathrm{n}$-Butanol $(\mathrm{kg} / \mathrm{kg})$ & 0.41 & 0.41 & 0.46 & 0.46 & 0.34 \\
\hline Lactic acid $(\mathrm{kg} / \mathrm{kg})$ & 1.00 & 1.00 & 1.11 & 1.13 & 0.82 \\
\hline Succinic acid $(\mathrm{kg} / \mathrm{kg})$ & 1.12 & 1.12 & 1.25 & 1.27 & 0.92 \\
\hline Xylitol $(\mathrm{kg} / \mathrm{kg})$ & 0.92 & 0.92 & 1.02 & 1.04 & 0.75 \\
\hline
\end{tabular}

*SCB composition: $42 \%$ Cellulose $31 \%$ hemicellulose and balance other constituents; ** see appendix I for calculations of yield

\section{Pre-treatment of sugarcane bagasse}

Making a complex lignocellulosic biomass amenable for further transformations is the critical first step in maximising its utilisation potential. The extent of biomass conversion is dependent on its superficial and supramolecular structure, lignin, cellulose and hemicellulose content, particle size and elemental composition. Specifically, with the structural composition of SCB, recalcitrance lies in the encapsulating lignin-hemicellulose structure shielding the valuable cellulose, cellulose crystallinity and lignin-holocellulose interlinks hindering its extent of utilisation. To enhance the bioavailability and thereby increase the valorisation potential of SCB, pretreatment methods are essential. An efficient pre-treatment method should not only be effective in terms of enhancing the sugar yields or making the biomass more bioavailable, but also be scalable and economical. Pre-treatment is considered to be the most expensive process step in a lignocellulosic biorefinery and can contribute to about $20 \%$ of the total cost, with the combined costs of pre-treatment, enzymatic production and hydrolysis accounting for up to $40 \%{ }^{30}$. Since it is the first step, it has a pervasive impact on the cost of all biological processing operations downstream. Hence the pre-treatment must be advanced and fully integrated with the rest of the process to harvest the complete potential of lignocellulosic biomass ${ }^{30}$. Therefore, choice of pre-treatment method becomes crucial for a SCB biorefinery. A range of SCB pre-treatment methods are reported in literature for two important applications, namely, enhancing saccharification (and bioethanol/value added product fermentation) and intensifying biogas generation. These methods are discussed in this section and summarised in Table 4.

Pre-treatment methods are generally classified into four categories; physical, chemical, biological and physico-chemical pre-treatment (Figure 2). Comminution is the most common physical pre-treatment where SCB is milled to a desirable particle size range. Milling not only helps in reducing the particle size or increasing the specific surface area, but concomitantly also affects the cellulose crystallinity. The combined effect of increased surface area and reduced crystallinity in turn facilitates enhanced enzymatic hydrolysis thereby improving the saccharification rate and yield. This in turn facilitates enhanced enzyme binding to the cellulose fractions of the biomass thereby improving the saccharification rate and yield 31, 32. Milling performance and the specific milling energy required are dictated by parameters such as the moisture content of SCB, required comminution ratio (ratio of initial particle size to final particle size) and the type of mill used. An increased moisture content leads to an increased energy draw as well as plugs the meshes. An increase in comminution ratio (decrease in final particle size) also leads to an increase in specific milling energy. For instance, using a bench scale knife mill, Miao et al reported that $\sim 720 \mathrm{kWh} /$ tonne dry weight is required to grind SCB ( $\sim 40 \%$ moisture content) from an initial size of $20-25.4 \mathrm{~mm}$ to a final particle size of $2 \mathrm{~mm}^{33}$. When the final particle size was $8 \mathrm{~mm}$, the energy requirement reduced to $\sim 390 \mathrm{kWh} /$ tonne dry weight. The aforementioned factors affect dry milling, whereas an alternative wet milling approach has also been exploited in literature to pre-treat SCB. For instance, da Silva et al, reported the use of wet disk milling as a method to pre-treat SCB for enhancing the saccharification yield ${ }^{31}$. Lab scale milling pre-treatment for enhanced saccharification of SCB is often reported ${ }^{34,35}$, however, the most important parameter, the specific milling energy requirement is hardly reported. In any case, the energy consumption values based on lab scale milling will not be relevant for the industrial scale milling. The data on energy requirements for large scale milling are not readily available.

Chemical pre-treatment typically utilises an acid or an alkali to hydrolyse or delignify the biomass. They may be used in conjunction with compressed hot water or saturated steam, so that the chemical pre-treatment method becomes a physicochemical method. Chemical pre-treatment methods often end up producing inhibitors (of fermentation) such as 5hydroxymethylfurfural, acetic acid, formic acid or furfural, under acidic conditions. The hydrolysates when not detoxified appropriately will negatively influence subsequent fermentation. Furthermore, as a general rule, biomass slurries upon chemical pre-treatment need to be neutralised prior fermentation/biogas generation and therefore may incur additional costs at scale.

Unlike chemical pre-treatment, biological pre-treatment involves the use of enzymes or microbes to delignify or hydrolyse SCB. A class of fungi known as the brown rot fungi produces extracellular lignolytic enzymes such as lignin peroxidases or laccases that help in delignification. A close ally, white rot fungi on the other hand can produce lignocellulolytic enzymes that can also hydrolyse cellulose (cellulase), in addition to breaking down lignin ${ }^{36}$. While biological methods have proven to be advantageous for delignification with low input energy requirements, the slow rate of pre-treatment is often seen as a significant disadvantage. On the other hand, the process also becomes expensive when highly pure enzymes are utilised for targeted pre-treatment and fractionation. 


\section{ARTICLE}

Table 4: Different pre-treatment methods for SCB

(a) For biogas production

\begin{tabular}{|c|c|c|c|c|c|}
\hline $\begin{array}{l}\text { Pre-treatment } \\
\text { type }\end{array}$ & Method and operating conditions & $\begin{array}{l}\text { Particle size } \\
(\mathrm{mm})\end{array}$ & $\begin{array}{l}\text { SCB concentration, g/L } \\
\text { (volume, } \mathrm{L} \text { ) }\end{array}$ & $\mathrm{CH}_{4}$ yield & Reference \\
\hline \multirow[t]{2}{*}{ Physical } & Milled to $<0.85 \mathrm{~mm}$ & 5 & - & Increase - $33 \%$ & $\begin{array}{l}\text { Kivaisi \& Eliapenda, } \\
1994^{37}\end{array}$ \\
\hline & Milled to $1 \mathrm{~mm}$ & $>10$ & - & Increase - $15 \%\left(\sim 310 \mathrm{ml} \mathrm{CH}_{4} / \mathrm{g} \mathrm{VS}\right)$ & Leite et al., $2015^{38}$ \\
\hline \multirow{4}{*}{ Chemical } & $\begin{array}{l}\mathrm{Ca}(\mathrm{OH})_{2}, 0.47 \mathrm{~g} \text { lime } / \mathrm{g} \text { dry matter, } 90^{\circ} \mathrm{C} \text {, } \\
150 \mathrm{rpm}, 90 \mathrm{~h}\end{array}$ & - & $\begin{array}{l}40-80 \\
(0.1)\end{array}$ & $\begin{array}{l}148-183 \mathrm{ml} \mathrm{CH}_{4} / \mathrm{g} \mathrm{COD} \text { (solid residue) } \\
\& 3.5 \mathrm{~L} \mathrm{CH}_{4} / \mathrm{L} \text { liquor }\end{array}$ & \multirow{2}{*}{ Rabelo et al., $2011^{39}$} \\
\hline & $\begin{array}{l}\text { Alkaline } \mathrm{H}_{2} \mathrm{O}_{2}, 7.36 \%(\mathrm{v} / \mathrm{v}), \mathrm{pH} 11.5,25^{\circ} \mathrm{C} \text {, } \\
150 \mathrm{rpm}, 1 \mathrm{~h}\end{array}$ & - & $\begin{array}{l}40-150 \\
(0.1)\end{array}$ & $\begin{array}{l}84-127 \mathrm{ml} \mathrm{CH}_{4} / \mathrm{g} \mathrm{COD} \text { (solid residue) } \\
\& 6.5 \mathrm{~L} \mathrm{CH}_{4} / \mathrm{L} \text { liquor }\end{array}$ & \\
\hline & $\mathrm{HCl}, 0.63-1.97 \mathrm{M}, 103-137^{\circ} \mathrm{C}, 6-74 \mathrm{~min}$ & \multirow[b]{2}{*}{1} & \multirow{2}{*}{$\begin{array}{l}100 \\
(0.5)\end{array}$} & Increase -36 to $122 \mathrm{ml} \mathrm{CH}_{4} / \mathrm{g}$ & \multirow[b]{2}{*}{ Costa et al., $2014^{40}$} \\
\hline & $\begin{array}{l}\mathrm{NaOH}, 0.8-1.8 \mathrm{M}, 116-184^{\circ} \mathrm{C}, 13-47 \\
\min \end{array}$ & & & Increase -36 to $139 \mathrm{ml} \mathrm{CH}_{4} / \mathrm{g}$ & \\
\hline $\begin{array}{l}\text { Physico- } \\
\text { chemical }\end{array}$ & $\begin{array}{l}\text { Vortex based hydrodynamic cavitation, } 0- \\
117 \text { passes, } 3.9 \text { barg }\end{array}$ & 2 & $\begin{array}{l}10 \\
(15)\end{array}$ & Increase -175 to $229 \mathrm{ml} \mathrm{CH}_{4} / \mathrm{g} \mathrm{VS}$ & $\begin{array}{l}\text { Nagarajan \& Ranade, } \\
2019^{41}\end{array}$ \\
\hline
\end{tabular}

(b) For sugar based fermentative products 


\begin{tabular}{|c|c|c|c|c|c|c|c|c|}
\hline \multirow{2}{*}{$\begin{array}{l}\text { Pre- } \\
\text { treatment } \\
\text { type }\end{array}$} & \multirow{2}{*}{$\begin{array}{l}\text { Method and operating } \\
\text { conditions }\end{array}$} & \multirow{2}{*}{$\begin{array}{l}\text { Initial } \\
\text { particle } \\
\text { size }(\mathrm{mm})\end{array}$} & \multirow{2}{*}{$\begin{array}{l}\text { SCB concentration, } \\
\text { g/L (volume, L) }\end{array}$} & \multirow{2}{*}{$\begin{array}{l}\text { Inhibitors } \\
\text { generated }\end{array}$} & \multirow{2}{*}{ Effect of pre-treatment } & \multicolumn{2}{|c|}{$\begin{array}{l}\text { Enhancement upon } \\
\text { enzymatic hydrolysis }\end{array}$} & \multirow{2}{*}{ Reference } \\
\hline & & & & & & $\begin{array}{l}\text { Glucose } \\
\text { yield }\end{array}$ & $\begin{array}{l}\text { Xylose } \\
\text { yield }\end{array}$ & \\
\hline \multirow{4}{*}{ Physical } & $\begin{array}{l}\text { Planetary ball milling, } \\
1-4 \mathrm{~h}\end{array}$ & $<1$ & $\begin{array}{l}50 \mathrm{~g} \text { in } 0.5 \mathrm{~L} \text { milling } \\
\text { cup }\end{array}$ & Acetic acid & $\begin{array}{l}\text { Complete conversion to } \\
\text { amorphous cellulose }\end{array}$ & $89 \%$ & $77 \%$ & $\begin{array}{l}\text { Buaban et al., } \\
2010^{35}\end{array}$ \\
\hline & Wet disk milling,0 - $143 \mathrm{~min}$ & $<2$ & $\begin{array}{l}50 \\
(20)\end{array}$ & Acetic acid & $\begin{array}{l}\text { Insignificant change in } \\
\text { cellulose crystallinity, } \\
\sim 20 \mu \text { m defibrillated } \\
\text { structure }\end{array}$ & $\begin{array}{l}22 \% \text { to } 49 \\
\%\end{array}$ & $\begin{array}{l}\sim 10 \% \\
\text { to } 37 \%\end{array}$ & $\begin{array}{l}\text { da Silva et al., } \\
2010^{31}\end{array}$ \\
\hline & $\begin{array}{l}\text { Wet disk milling, } \\
0-71 \mathrm{~min}\end{array}$ & 2 & $\begin{array}{l}20 \\
(3)\end{array}$ & - & $\begin{array}{l}\text { 14-fold increase in } \\
\text { specific surface area }\end{array}$ & $\begin{array}{l}13 \% \text { to } 62 \\
\%\end{array}$ & $\begin{array}{l}10 \% \text { to } \\
43 \%\end{array}$ & $\begin{array}{l}\text { Barros et al., } \\
2013^{34}\end{array}$ \\
\hline & $\begin{array}{l}\text { Soaked in glycerol for } 24 \mathrm{~h} \text {, then } \\
\text { microwave }(2450 \mathrm{MHz}) \text { for } 5 \mathrm{~min}\end{array}$ & 3 & $\begin{array}{l}333 \\
(0.03)\end{array}$ & - & $\begin{array}{l}\text { Partial removal of } \\
\text { hemicellulose } \\
\text { (corresponding increase } \\
\text { in cellulose\%) }\end{array}$ & $2 \%$ to $35 \%$ & - & $\begin{array}{l}\text { de Cassia } \\
\text { Pereira et al., } \\
2015^{42}\end{array}$ \\
\hline \multirow{2}{*}{ Biological } & $\begin{array}{l}\text { Pleurotus florida, Coriolopsis } \\
\text { caperata RCK } 2011 \text { \& } \\
\text { Ganoderma sp. rckk-02, } 0.5 \mathrm{~g} / \mathrm{L} \\
\text { inoculum, } 30^{\circ} \mathrm{C}, 25 \text { days, } \mathrm{pH} 5.5\end{array}$ & $1-2$ & $\begin{array}{l}40 \\
(0.5)\end{array}$ & - & $5-8 \%$ removal of lignin & \multicolumn{2}{|c|}{$\begin{array}{l}\text { Increase in total } \\
\text { reducing sugars from } \\
20 \% \text { to } 49 \%\end{array}$} & $\begin{array}{l}\text { Deswal et al., } \\
2014^{43}\end{array}$ \\
\hline & $\begin{array}{l}\text { Ceriporiopsis subvermispora, } \\
0.5 \mathrm{~g} / \mathrm{kg} \mathrm{SCB} \text { inoculum, } 27^{\circ} \mathrm{C}, 7- \\
60 \text { days, } \mathrm{pH} 5.5\end{array}$ & - & $\begin{array}{l}25 \text { g soaked in water } \\
\text { \& autoclaved }\end{array}$ & - & $\begin{array}{l}48 \% \text { removal of cellulose } \\
47 \% \text { removal of } \\
\text { hemicellulose }\end{array}$ & $\begin{array}{l}\text { Increase } \\
\text { from } 23 \%- \\
55 \%\end{array}$ & - & $\begin{array}{l}\text { Machado \& } \\
\text { Ferraz, } \\
2017^{44}\end{array}$ \\
\hline \multirow[t]{2}{*}{$\begin{array}{l}\text { Physico- } \\
\text { chemical }\end{array}$} & $\begin{array}{l}\mathrm{SO}_{2} / \mathrm{H}_{2} \mathrm{SO}_{4} \text { catalysed steam } \\
\text { explosion, } 130-205^{\circ} \mathrm{C}, 5-60 \\
\text { min }\end{array}$ & - & $\begin{array}{l}25-111 \mathrm{~g} / \mathrm{L} \\
\text { impregnated with } \sim 2 \\
\% \mathrm{SO}_{2} \text { and/or } \sim 1 \% \\
\mathrm{H}_{2} \mathrm{SO}_{4}\end{array}$ & $\begin{array}{l}\text { Furfural, } \\
\text { acetic acid \& } \\
\text { 5-HMF }\end{array}$ & $\begin{array}{l}50-60 \% \text { solubilisation of } \\
\text { hemicellulose }\end{array}$ & $92 \%$ & $82 \%$ & $\begin{array}{l}\text { Carrasco et } \\
\text { al., } 2010^{45} \text {, }\end{array}$ \\
\hline & $\begin{array}{l}\text { Steam explosion, } \\
190^{\circ} \mathrm{C}, 15 \mathrm{~min}\end{array}$ & - & $\begin{array}{l}80 \\
(250)\end{array}$ & - & $\begin{array}{l}\sim 75 \% \text { solubilisation of } \\
\text { hemi-cellulose }\end{array}$ & - & - & $\begin{array}{l}\text { Rocha et al., } \\
2020^{46}\end{array}$ \\
\hline
\end{tabular}




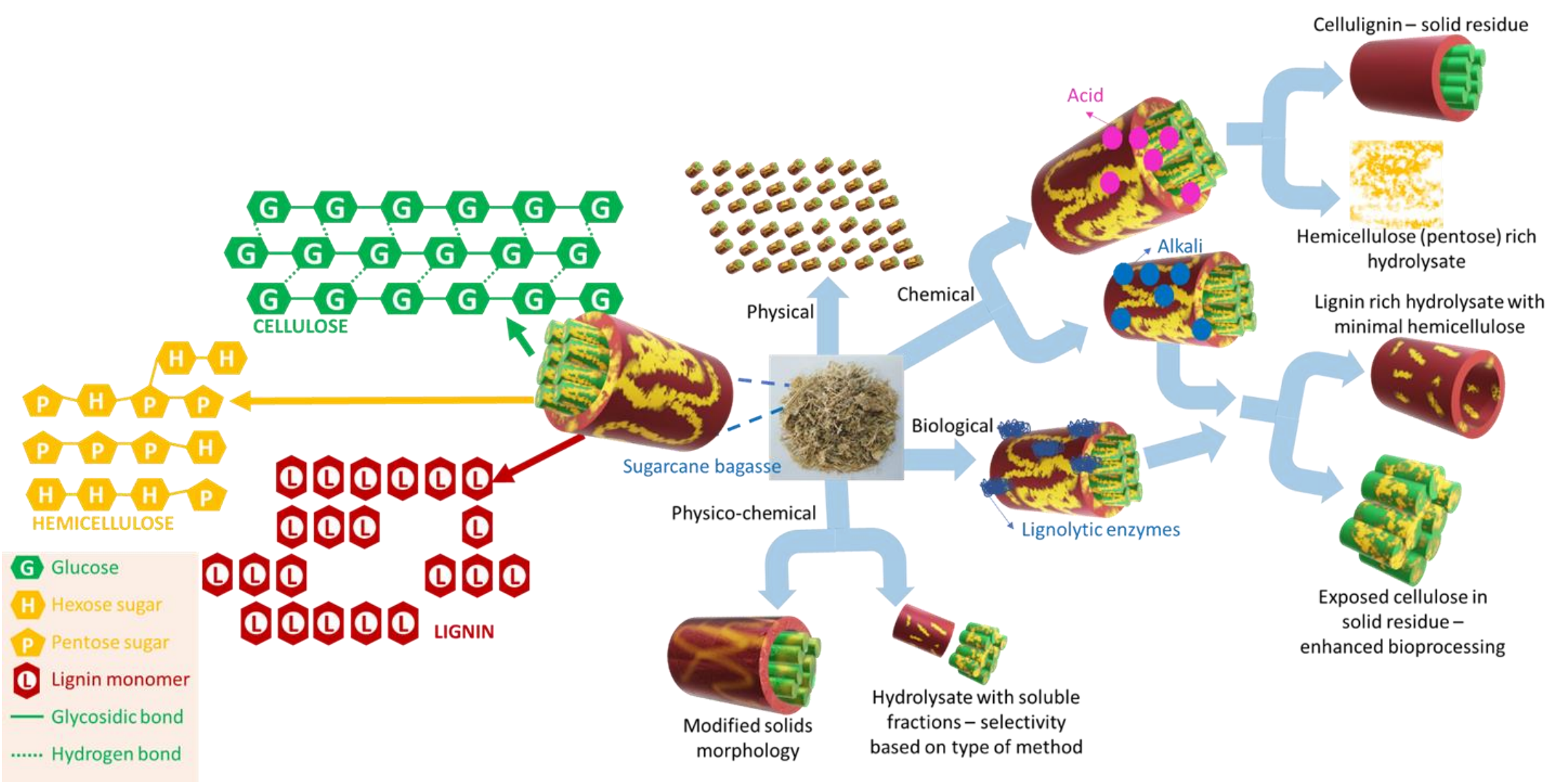

Figure 2: Lignocellulose pre-treatment methodologies. 
However, it may be possible to recover and recycle enzymes to reduce the overall pre-treatment cost ${ }^{47}$.

Physico-chemical methods are attractive pre-treatment options as they potentially overcome the disadvantages posed by other techniques. Steam explosion with mild acid or alkali has particularly gained interest for SCB pre-treatment to enhance its saccharification potential and in turn bioethanol yields ${ }^{46,48-}$ 50. Furthermore, it has also been proposed to be an energy efficient pre-treatment method for bioethanol production ${ }^{51}$. The rapid depressurisation during steam explosion facilitates physical pre-treatment by breaking the fibres while the acid/alkali will catalyse hydrolysis or delignification of the biomass. The process conditions can be tuned to obtain C5 sugar rich hydrolysate and cellulose rich residue. Physicochemical pre-treatment seems a promising method in terms of scalability and energy efficiency, not only for saccharification or bioethanol production but also for enhancing biogas yields via anaerobic digestion (AD) of SCB. For instance, the use of hydrodynamic cavitation $(\mathrm{HC})$ as a biomass pre-treatment method is increasing rapidly $41,52,53$. HC is the phenomenon of formation, growth and implosion of vaporous cavities. HC occurs in a flowing fluid as a result of local drop in pressure due to the design geometry. During HC pre-treatment, reactive radical species generated in situ from the cleavage of water molecules chemically pre-treats the biomass, whereas the collapsing cavities induce shear and physically pre-treat the biomass, affecting the particle size and morphology.

Various pre-treatment categories were introduced earlier in the section; however, it is important to match specific methods to the end applications. For example, anaerobic digestion being a robust technology can handle toxins well when compared to classic sugar fermentation, therefore, detoxification maybe required prior to fermentation, whereas they may not be necessary for biogas generation applications. Similarly, breaking open the biomass structure would be sufficient to enhance biogas yields, whereas fractionation is required for enhanced saccharification and fermentation. Therefore, a few examples from literature are specifically presented for these two main applications, namely (i) biogas production (Table 4a) and (ii) saccharification (both $\mathrm{C} 5$ and $\mathrm{C} 6$ sugars) leading to fermentation (Table 4b).

The simplest pre-treatment that can be performed for enhancing biogas generation is comminution. ${ }^{37}$ reported an enhanced biogas generation of up to $33 \%$ for a comminution ratio of 5.8 with the final SCB particle size being $0.85 \mathrm{~mm} .{ }^{38}$ on the other hand reported an enhancement of up to $15 \%$ in biogas yield for a comminution ratio of 10 for a final particle size of $1 \mathrm{~mm}$. Although the final particle sizes were similar in both cases, with the comminution ratio for Leite et al. being almost twice as much as the former, the improvement in biogas observed was almost half as much. While both the groups used SCB that had a VS content of over $90 \%$ (on dry basis), the lignin content differed significantly (Kivaisi \& Eliapenda reported a lignin content of SCB $9 \%$ as compared to Leite et al at $16 \%$ ), which may have influenced the variation in the enhancement observed.

Chemical methods have been reported extensively to improve biogas generation. For instance, Rabelo et al. (2011) utilised calcium hydroxide (lime) to pre-treat SCB at $90{ }^{\circ} \mathrm{C}$ for $90 \mathrm{~h}{ }^{39}$. They used a lime loading of $0.47 \mathrm{~g} / \mathrm{g} \mathrm{SCB}$ and observed a decrease in lignin and hemicellulose content from $23 \%$ to $20 \%$ and $25 \%$ to $13 \%$, respectively. A corresponding increase in cellulose content in the solid residue up to $66 \%$ (from $38 \%$ ) was also reported. When alkaline hydrogen peroxide treatment was opted $(7.36 \% \mathrm{v} / \mathrm{v})$ at room temperature for $1 \mathrm{~h}$ to pre-treat SCB, a much higher increase in cellulose content was observed in the residue $(81 \%)$. Both these methods favoured enhanced biogas yields from the solid residue upon pre-treatment. Additionally, to test the possibility of a biorefinery, the solid residue rich in cellulose was utilised for saccharification and the liquor was subjected to biomethanation potential (BMP) tests. Alkaline peroxide treatment was favourable for supporting biogas generation from the liquor due to the higher quantity of hemicellulose solubilised from SCB (corresponding xylan content in solids reduced from $25 \%$ to $8 \%$ ). Costa et al. (2014), utilised conventional sodium hydroxide pre-treatment to delignify SCB ( $1 \mathrm{~mm}$ particle size) ${ }^{40}$. They reported a $26 \%$ lignin removal that resulted in a 3.8 fold increase in biomethane production to $139 \mathrm{~L} \mathrm{CH}_{4} / \mathrm{kg}$ substrate. While alkali pretreatment is generally favoured for delignification, acid hydrolysis is exploited for solubilising hemicellulose (minimal acid soluble lignin) to produce cellulignin (solid residue rich in cellulose and lignin). However, the type of acid influences the outcome upon pre-treatment. For example, for enhancing biogas production, when $\mathrm{H}_{2} \mathrm{SO}_{4}$ is used to pre-treat $\mathrm{SCB}$, the sulfates formed during the neutralisation stage have to be removed, otherwise, the biomethane yields will be compromised. This is due to the action of a class of bacteria known as the sulfate reducing bacteria (SRB) present in the digester. SRB utilises sulfate and compete with methanogens for protons from the feedstock/volatile fatty acids, thereby reducing the available protons for methane generation. Costa et al, therefore reported the use of $\mathrm{HCl}$ for the pre-treatment of $1 \mathrm{~mm}$ SCB particles for enhancing the biomethane production. 
They achieved $>50 \%$ solubilisation of holocellulose that favoured an increase in BMP up to $122 \mathrm{~L} \mathrm{CH}_{4} / \mathrm{kg}$ substrate (3.4 times increase). The increase in BMP upon acid pre-treatment was lower as compared to alkali pre-treatment, reiterating the fact that lignin induced recalcitrance hinders holocellulose bioavailability and therefore must be removed.

Nagarajan and Ranade (2019) reported a novel vortex based HC pre-treatment to enhance the biogas yields from SCB. The novel vortex based device used by ${ }^{41}$ harnessed $\mathrm{HC}$ using a vortex flow based device invented by ${ }^{54}$. It has eminent advantages over conventional linear flow devices, such as no small constrictions, cavitation occurring in the core and away from the walls leading to no device erosion and hence requiring minimum maintenance. Additionally, the energy required for vortex based HC pre-treatment of SCB was reported to be 140 $\mathrm{kWh} /$ tonne dry weight (for a low biomass loading of $1 \%$ ) which was significantly lower than the milling energy mentioned earlier and other $\mathrm{HC}$ devices used for agricultural residue pretreatment 55,56 .

Mechanical grinding is known to improve the enzymatic saccharification efficiency. Accordingly, milling pre-treatment for enhanced saccharification of SCB is often reported $31,34,35$ da Silva et al compared ball milling and wet disk milling of $2 \mathrm{~mm}$ SCB particles based on the saccharification efficiency. With the untreated SCB yielding $22 \%$ glucan upon enzymatic hydrolysis, ball milled SCB yielded $>80 \%$ and wet disk milled SCB yielded 49 $\%$. The ability of ball milling to completely convert the crystalline cellulose in SCB to amorphous cellulose was attributed as the reason for such a high saccharification yield.

Deswal et al. (2014) utilised three white rot fungi, namely, Pleurotus florida, Coriolopsis caperata RCK 2011 and Ganoderma sp. rckk-02 to delignify SCB ${ }^{43}$. Highest delignification of $8 \%$ was observed when P.florida was used to treat SCB for 25 days. The solids residue upon recovery was subjected to enzymatic saccharification that yielded $49 \%$ reducing sugars as compared to untreated SCB (20\%). More recently, Machado and Ferraz reported delignification of SCB using Ceriporiopsis subvermispora ${ }^{44}$. Autoclaved material when subjected to fungal fermentation facilitated the removal of 47 $\%$ lignin and $48 \%$ hemicellulose in 60 days. This favoured the enzymatic saccharification of cellulose rich residue and increased the glucan yield to $55 \%$ from $23 \%$.

Carrasco et al.(2010) performed steam explosion of $\mathrm{SO}_{2}$ impregnated SCB at their optimised conditions of $190{ }^{\circ} \mathrm{C}$ for 5 min to obtain a xylose yield of $\sim 60 \%{ }^{45}$. Fermentation inhibitors such as acetic acid, furfural and 5-hydroxymethylfurfural were also observed in the hydrolysate along with the xylose and xylooligomers. The solid residue upon pre-treatment was saccharified using an enzyme cocktail that yielded $90 \%$ glucose at $2 \%$ solid loading. Carvalho et al. (2018), was able to achieve similar xylose yields by using a higher concentration of $\mathrm{SO}_{2}$ in combination with a lower temperature $\left(3 \%, 150{ }^{\circ} \mathrm{C}\right.$ and $\left.30 \mathrm{~min}\right)$ 48. Swapping $\mathrm{SO}_{2}$ with $0.5 \% \mathrm{H}_{2} \mathrm{SO}_{4}$ and reducing the time by half also yielded similar concentrations of xylose in the hydrolysate. They also demonstrated that autocatalytic steam explosion (without an added catalyst) is selective towards xylooligosaccharides whereas in the presence of an acid catalyst, xylose production was favoured. More recently, autocatalytic steam explosion at $190^{\circ} \mathrm{C}$ for $15 \mathrm{~min}$ was performed with $80 \mathrm{~g} / \mathrm{L}$ $\mathrm{SCB}$ in a $250 \mathrm{~L}$ pressure reactor by ${ }^{46}$ to recover hemicellulose rich hydrolysate ( $90 \%)$. The solid residue (cellulignin) was further treated with $1 \% \mathrm{NaOH}$ aqueous solution under oxygen pressure to solubilise lignin and leave behind a pure cellulose rich solid residue. With tuneable parameters paving way for selective fractionation and inhibitor minimisation, steam explosion is a suitable candidate for pilot and industrial trials aiming at bioethanol production. Accordingly, there have been a few studies at demo scale level to produce xylose rich hydrolysates continuously from SCB (e.g DBT-ICT technology and Praj Industries, India) ${ }^{57-59 .}$

Other pre-treatment methods have also been utilised for SCB pre-treatment such as microwave ${ }^{42}$, compressed hot water ${ }^{60}$, organosolv 61, ionic liquids 62, ammonia fibre explosion 63, supercritical $\mathrm{CO}_{2}{ }^{64}$, acoustic cavitation ${ }^{65}$, photocatalysis 66 , gamma radiation 67 , Fenton's reagent 68 and ensiling pretreatment ${ }^{69}$. These methods are however not discussed in this review as they are mainly restricted to lab scale, expensive, energy intensive or not scalable at this point of time. The readers are henceforth directed to the references directly to know more on these methods. Amongst the pre-treatment methods discussed, (catalytic) steam explosion and hydrodynamic cavitation for bioethanol production and biogas generation respectively seem promising options for scale up with economic feasibility and therefore may be used to realise a bagasse based biorefinery.

\section{SCB to biogas}

Biogas is an admixture of methane and carbon dioxide predominantly. Negligible quantities of ammonia, hydrogen sulphide, hydrogen, nitrogen and water vapour may also be present. Biogas when upgraded to compressed biogas (CBG) containing $>90 \% \mathrm{CH}_{4}$ can be utilised as a transportation fuel and is analogous to compressed natural gas (CNG). Biogas is primarily produced from anaerobic digestion (AD) of organic matter. $A D$ is a complex synergistic microbial process that occurs in the absence of oxygen. The carbon and electron source to sustain microbial growth and metabolism comes from the organic matter being fed. AD has the capability to utilise complex feedstock such as agricultural residue for biogas generation (e.g. SCB).

Neither AD nor biogas is alien to India. In fact, the world's first biogas plant was built in Bombay (now Mumbai), India in 1859 that utilised sewage sludge as the feedstock ${ }^{70}$. Currently, the total biogas production in India is 2.07 billion $\mathrm{m}^{3} /$ year. This is quite low compared to its potential, which is estimated to be in the range of $29-48$ billion $\mathrm{m}^{3} /$ year $^{71}$. In the current context, with the policy drivers in India clearly pointing towards a biogas 
market, it is important that the current subsidies provided by Gol are leveraged. To build base and boost the capacity for biogas generation, the Ministry of Petroleum and Natural Gas initiated the Sustainable Alternative Toward Affordable Transportation (SATAT) scheme in late $2018^{72}$. The crux of this scheme was to create a buy in for CBG (compressed biogas) produced from waste biomass sources ( $₹ 46 / \mathrm{kg} C B G$ ) ${ }^{73}$ and utilise it as a sustainable transportation fuel. The initial expression of interest call aimed at supporting the phased setup of 5000 biogas plants spanning across India. Recently, the Reserve Bank of India (RBI) has also included CBG plants under priority sector lending. With India being the world's second largest producer of sugarcane ( 303.83 million tonnes in 2019) and $\sim 30 \%$ ending up as SCB (91.15 million tonnes) and operating over 500 sugar mills, the availability of SCB as a feedstock for biogas generation via $A D$ fits the purpose precisely. As per the notification from Department of Agriculture and Farmers Welfare, Gol (13 th July 2020), the fermented organic digestate coming out from $A D$ of $\mathrm{SCB}$ /other agro wastes is now approved as organic manure in Fertilizer Control Order (FCO). The enhanced and readily available nitrogen in the digestate when used as organic fertilizer would partly or fully offset the need for chemical fertilizers which in itself has a high energy demand during production ${ }^{74}$. This will immensely help the biogas and CBG sector in future.

Biogas generation from SCB is dependent on its composition, particle size and morphology. The cellulose and hemicellulose fractions together in SCB constitute about $60-70 \%$ of its dry weight (or total solids, TS) and can be predominantly utilised towards biogas generation. Lignin generally remains unaffected, however can hinder the effective utilisation of the polysaccharides. Therefore, complete conversion of the holocellulose fraction is unlikely. Inherent variability in the composition of SCB can occur due to the species of cane utilised, time of harvest or varying efficiencies of juice extraction. For instance, Janke et al. (2015) sampled SCB from plants located in two different Brazilian states in two different seasons and tested the biochemical methanation potential (BMP) of these variants. With the volatile solids (VS) content not overly different (96 $\pm 2.7 \%$ of TS), a huge variation in BMP was observed between the two samples, namely 236 and $326 \mathrm{ml}$ $\mathrm{CH}_{4} / \mathrm{g}$ VS. They attributed this difference to the varying quantities of easily utilisable residual non-structural carbohydrates in SCB present upon juice extraction. Using the elemental composition of SCB, theoretical BMP can be calculated using the Buswell equation. The theoretical maximum varies in the range of $425-487 \mathrm{ml} \mathrm{CH}_{4} / \mathrm{g}$ VS for SCB 41. Theoretical BMP is calculated based on the assumption that all VS can be utilised towards biogas generation. In reality, however this can never be achieved. The experimental BMP of SCB reported in literature spans over a broad range from 37 (assuming a VS content of $96 \%$ of TS) 40 to $326 \mathrm{ml} \mathrm{CH}_{4} / \mathrm{g} \mathrm{VS} 75$, while the typical range is $170-250 \mathrm{ml} \mathrm{CH}_{4} / \mathrm{g} \mathrm{VS}$. Pre-treatment has the capability to improve the BMP. The influence of pretreatment on biogas production with typically observed biogas generation profiles are captured in Figure 3. A variety of studies reporting an increase in BMP upon SCB pre-treatment are summarised in Table 5.

Table 5: Enhanced biochemical methanation potential from SCB upon pre-treatment.

\begin{tabular}{|c|c|c|c|c|}
\hline $\begin{array}{l}\text { SCB initial particle } \\
\text { size }(\mathrm{mm})\end{array}$ & Pre-treatment and operating conditions & $\begin{array}{l}\text { BMP upon pre- } \\
\text { treatment (ml } \\
\mathrm{CH}_{4} / \mathrm{g} \text { VS) }\end{array}$ & $\begin{array}{l}\text { Increase in } \\
\text { BMP (\%) }\end{array}$ & Reference \\
\hline$\leq 1$ & $\begin{array}{l}10 \mathrm{~g} \text { SCB soaked in } 140 \mathrm{~g} \text { aqueous ethanolic } \\
\text { ammonia ( } 10 \% \text { ammonia }+25 \% \text { ) ethanol, } 70{ }^{\circ} \mathrm{C} \\
\text { for } 12 \mathrm{~h} \text {, solids used for BMP }\end{array}$ & 249 & $135 \%$ & $\begin{array}{l}\text { Sajad Hashemi } \\
\text { et al., } 2019^{76}\end{array}$ \\
\hline 5 & Milled to $<0.85 \mathrm{~mm}$ & - & $33 \%$ & \multirow{4}{*}{$\begin{array}{l}\text { Kivaisi \& } \\
\text { Eliapenda, } \\
1994^{37}\end{array}$} \\
\hline \multirow{3}{*}{$\leq 2$} & $1 \mathrm{M} \mathrm{NaOH}$ for 30 days & - & $44 \%$ & \\
\hline & $1 \mathrm{M} \mathrm{HCl}$ for 30 days & - & $32 \%$ & \\
\hline & $1 \mathrm{M} \mathrm{NH}_{4} \mathrm{OH}$ for 30 days & - & $22 \%$ & \\
\hline$\leq 2$ & $\begin{array}{l}\text { Vortex based hydrodynamic cavitation - } 9 \\
\text { passes }\end{array}$ & 229 & $24 \%$ & $\begin{array}{l}\text { Nagarajan \& } \\
\text { Ranade, } 2019^{41} \\
\end{array}$ \\
\hline$\leq 3$ & $\begin{array}{l}100 \mathrm{~g} / \mathrm{L} \mathrm{SCB} \text {, hydrothermal pre-treatment, } 180 \\
{ }^{\circ} \mathrm{C}, 1931 \mathrm{kPa}, 20 \text { min followed by } 8.5 \% \text { lime } \\
\text { treatment for } 4 \text { days }\end{array}$ & 220 & $61 \%$ & $\begin{array}{l}\text { Mustafa et al., } \\
2018^{77}\end{array}$ \\
\hline \multirow{2}{*}{$\begin{array}{l}\leq 10(>68 \% \mathrm{SCB} \text { in } \\
\text { the range of } 0.18- \\
1.6 \mathrm{~mm})\end{array}$} & $\begin{array}{l}18.6 \mathrm{~g} / \mathrm{L} \mathrm{SCB}, 2 \%(\mathrm{w} / \mathrm{v}) \mathrm{H}_{2} \mathrm{SO}_{4} \text {, autoclaved, } 121 \\
{ }^{\circ} \mathrm{C}, 15 \mathrm{~min}\end{array}$ & 200 & $34 \%$ & \multirow[b]{2}{*}{$\begin{array}{l}\text { Badshah et al., } \\
2012^{78}\end{array}$} \\
\hline & $\begin{array}{l}18.6 \mathrm{~g} / \mathrm{L} \mathrm{SCB}, 2 \%(\mathrm{w} / \mathrm{v}) \mathrm{H}_{2} \mathrm{SO}_{4} \text {, autoclaved, } 121 \\
{ }^{\circ} \mathrm{C}, 15 \mathrm{~min} \text {, solid residue enzymatically } \\
\text { saccharified - Accellerase } 1500,60 \mathrm{~h}\end{array}$ & 173 & $16 \%$ & \\
\hline$>10$ & Milled to $1 \mathrm{~mm}$ & $\sim 310$ & $\sim 15 \%$ & $\begin{array}{l}\text { Leite et al., } \\
2015^{38}\end{array}$ \\
\hline
\end{tabular}




\begin{tabular}{|l|l|l|l|l|}
\hline 1.7 & $\begin{array}{l}240 \mathrm{~g} / \mathrm{L} \mathrm{SCB}, \text { hydrothermal pre-treatment, } 178.6 \\
{ }^{\circ} \mathrm{C}, 43.6 \mathrm{~min}, \text { hemicellulose rich hydrolysate for } \\
\mathrm{AD}, \mathrm{OLR}-2.4 \mathrm{~g} \mathrm{COD} / \mathrm{L} / \mathrm{day}\end{array}$ & $270^{*}$ & - & $\begin{array}{l}\text { Ribeiro et al., } \\
2017^{79}\end{array}$ \\
\hline
\end{tabular}

$* \mathrm{ml} \mathrm{CH}_{4} / \mathrm{g} \mathrm{COD}$

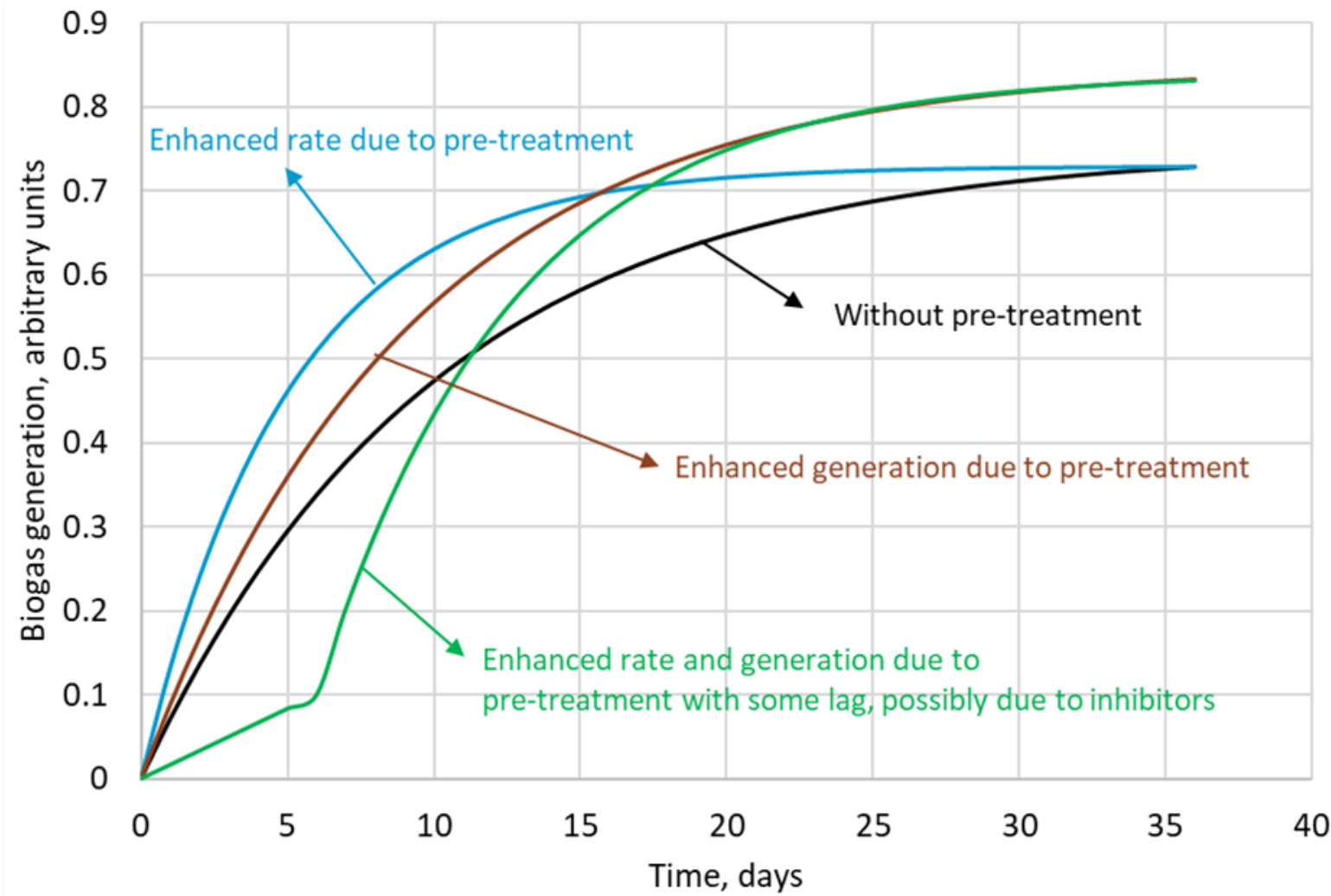

Figure 3: Influence of pre-treatment on biogas generation rate and yield.

Sajad Hashemi et al (2019) subjected milled SCB (1 mm) to ethanolic ammonia pre-treatment to enhance the BMP ${ }^{76}$. Equal weight of $10 \% \mathrm{v} / \mathrm{v}$ aqueous ammonia was mixed with a range of ethanol-water mixtures (5-50 \%) and $10 \mathrm{~g}$ milled SCB was soaked to the resulting ethanol-ammonia aqueous solution. Pre-treatment was performed in a closed reagent bottle at either 50 or $70^{\circ} \mathrm{C}$ for 12 or $24 \mathrm{~h}$. BMP of the untreated milled SCB, neutralised solid fraction, ethanol-ammonia free liquid and slurry were utilised for batch mesophilic BMP tests. Highest BMP was obtained from the solid ( $249 \mathrm{ml} \mathrm{CH}_{4} / \mathrm{g} \mathrm{VS}$ ) and liquid (298 $\mathrm{ml} \mathrm{CH}_{4} / \mathrm{g} \mathrm{VS}$ ) fractions (pre-treated at $70{ }^{\circ} \mathrm{C}$ for $12 \mathrm{~h}$ with $10 \%$ ammonia and $25 \%$ ethanol). With the case of the slurry, an increase in BMP was observed with an increase in pretreatment severity $\left(299.3 \mathrm{ml} \mathrm{CH}_{4} / \mathrm{g}\right.$ VS upon pre-treatment at $70{ }^{\circ} \mathrm{C}$ for $24 \mathrm{~h}$ with $10 \%$ ammonia and $50 \%$ ethanol). The obtained methane yield was over 2 -folds higher than that observed with untreated milled SCB. Delignification and breakdown of lignin-carbohydrate bonds were ascribed to be the reasons contributing towards an enhanced BMP.

Leite et al (2015) performed batch BMP experiments with raw SCB ( 10 mm particle size), milled SCB $(1 \mathrm{~mm})$ and lime treated milled SCB $(10 \% \mathrm{w} / \mathrm{w}$, lime/SCB in $24 \mathrm{ml}$ water for $24 \mathrm{~h}){ }^{38}$. They achieved a $20 \%$ increase in biomethane yield upon milling pre- treatment, whereas an alkali pre-treatment step post milling improved the yield by $50 \%$. They suggested that lime treatment might be economically feasible upon recycling the liquid phase, however, no cost analysis was presented. Mustafa et al (2018) also utilised lime pre-treatment as a strategy to enhance the BMP of $3 \mathrm{~mm} \mathrm{SCB}{ }^{77}$. They used $8.5 \%$ lime and pre-treated SCB for 4 days to achieve an increase in biogas yield by $23 \%$. They attributed the enhancement to the delignification observed as a result of lime pre-treatment. When hydrothermal pretreatment (compressed hot water) was opted at $180{ }^{\circ} \mathrm{C}$ for 20 $\min ,>35 \%$ increase in biogas yield was observed. The methane content in biogas for all the cases were observed to be over 65 $\%$. Upon hydrothermal pre-treatment, a diauxic digestion trend was observed which indicates that there may have been production of inhibitors during pre-treatment. When hydrothermal pre-treatment was combined with lime pretreatment sequentially, the biomethane yield enhancement observed was over $61 \%$. In contrast to hydrothermal pretreatment, a single digestion stage was observed upon sequential pre-treatment indicating that the inhibitors that might have been produced did not interfere with the microbial metabolism. The enhanced energy that was produced upon sequential pre-treatment was calculated to be $366 \mathrm{kWh} /$ tonne dry weight (difference of energy in methane obtained from pre- 
treated SCB and untreated SCB). Without taking into account the energy required for milling, considering the energy required to heat water for hydrothermal pre-treatment $(210 \mathrm{kWh} /$ tonne dry weight), the sequential pre-treatment yielded biomethane with a net energy gain of $156 \mathrm{kWh} /$ tonne dry weight.

Nagarajan and Ranade (2019) used a vortex based HC device to pre-treat $2 \mathrm{~mm}$ SCB particles at a solid loading of $1 \%(\mathrm{w} / \mathrm{w})$ for 9 passes through the device ${ }^{41}$. The energy required for pretreatment was $140 \mathrm{kWh} /$ tonne dry weight (for $1 \%$ solid loading) and the net energy gain achieved was $398 \mathrm{kWh} /$ tonne dry weight from the enhanced biomethane yield achieved (24\%). Modified surface morphology, particle size reduction and chemical compositional alternation due to cavitation pretreatment were attributed to be the reasons for an enhanced biomethane production. Assuming the energy gain due to the enhanced biomethane generation stayed constant at 537 $\mathrm{kWh} /$ tonne dry weight for various solid loading, the net energy gain will increase with increased solid loading. For example, 5\% solid loading (based on dry weight of SCB) will enhance net energy gain to more than $500 \mathrm{kWh} /$ tonne of dry SCB with 9 pass $\mathrm{HC}$ pre-treatment. $\mathrm{HC}$ therefore appears to be a promising method to pre-treat SCB for enhancing the biomethane production. Additionally, hybrid treatment methods such as alkali in combination with $\mathrm{HC}$ may also be tested to specifically improve delignification of SCB for further enhancing the BMP.

While batch BMP tests are indicative of the biomethane potential of pre-treated (and untreated) SCB, they do not effectively present the long term effect of pre-treatment on digestion performance. Continuous $A D$ tests are therefore important to assess this criterion. A proper understanding of the industrial scale anaerobic digesters' behaviour can be studied by conducting lab scale continuous/semi-continuous AD using relevant operating conditions ${ }^{80}$. One of the crucial operating conditions that needs to be considered for continuous $A D$ is the organic loading rate (OLR). Optimal OLR must be identified for a stable continuous $A D$ performance 81 , ${ }^{82}$. Sub optimal OLR can cause digester failure whereas high OLR can cause digester acidification. For instance, Ribeiro et al. (2017) hydrothermally pre-treated $240 \mathrm{~g} / \mathrm{L} \mathrm{SCB}$ at $178.6^{\circ} \mathrm{C}$ for $43.6 \mathrm{~min}$ and utilised the hemicellulose rich hydrolysate for continuous biogas production. During their investigation, they varied the OLR from $1.2-4.8 \mathrm{~g} \mathrm{COD} / \mathrm{L} /$ day and reported that the highest COD conversion of $86 \%$ was observed at an OLR of $2.4 \mathrm{~g} \mathrm{COD/L/day.} \mathrm{When} \mathrm{the} \mathrm{OLR} \mathrm{was} \mathrm{further} \mathrm{doubled,} \mathrm{the}$ conversion fell to $74 \%$. The conversion of COD to biogas was lower at a higher OLR due to the increased formation of volatile fatty acids and increased accumulation of inhibitors such as HMF that may have altered the microbial synergy required for optimum biogas generation. Another parameter that needs attention in continuous $A D$ is the quantity of inoculum added to the digester during start-up. Batch BMP utilises an inoculum to substrate ratio of $2: 1$ or 1:1 on the basis of VS. However, for continuous digesters, this might not be the case and therefore, during digester start up, the proportion of substrate added to the inoculum should be thoroughly thought through.
$A D$ when compared to other renewable energy technologies requires the least capital cost ${ }^{83}$. To further add value, $A D$ should not only be considered for biogas generation, rather considered as the base of a viable biorefinery. SCB may be partially converted in $A D$ and the resulting digestate would contain the unconverted holocellulose fraction with the loosened fibre matrix due to microbial activity ${ }^{84}$. This digestate may be used for further value addition without needing expensive chemical or enzymatic pre-treatment. Thus, AD may be used as a base for the biorefinery not only to recover energy in the form of biogas/CBG, but also to open up lignocellulosic matrix of unconverted biomass in digestate which can be converted to sugars and other value added products (see next section).

\section{SCB to alcohols and acids}

Efficient hydrolysis of SCB and hassle-free production of renewable $2 \mathrm{G}$ sugars creates a compelling commercial opportunity for fermentative production of chemicals. Like any other lignocellulosic material, the two major sugars present in SCB are glucose (C6) and xylose (C5). Most of the studies carried out using SCB as feedstock have focussed on the production of ethanol and xylitol. Cellulosic fraction was utilized for ethanol production while the hemicellulosic part was employed for xylitol accumulation 28,85 .

\section{Bioethanol}

Current global ethanol supply is produced mainly from edible (sugar and starch) feedstocks and is however not sustainable. Therefore, second generation lignocellulosic ethanol production has received significant attention ${ }^{86}$, as it promotes energy sustainability and decreases net greenhouse gas emissions. SCB is the most investigated lignocellulosic material for $2 \mathrm{G}$ ethanol production ${ }^{28}$. Saccharomyces cerevisiae, a conventional yeast, is the most studied and commercial microorganism for the fermentative ethanol production. It shows high resistance to ethanol and inhibitors present in hydrolysate. However, it cannot ferment C5 sugars released from the hemicellulosic fraction to ethanol due to the absence of required genes for assimilation of these sugars ${ }^{87} . \mathrm{S}$. cerevisiae has been metabolically engineered to confer xylose based ethanol production. However, there are no commercially used strains capable of converting C5 sugars into ethanol efficiently ${ }^{88,89}$. Different pre-treatments, methods of hydrolysis and fermentation modes have varying impacts on glucose release and eventually on ethanol production. The maximum theoretical yield of ethanol on glucose is $0.51 \mathrm{~g} / \mathrm{g}$ and the yield obtained with separate hydrolysis and fermentation (SHF) is in the range of $0.40-0.46 \mathrm{~g} / \mathrm{g}$. However, lower yields (0.31-0.38 $\mathrm{g} / \mathrm{g}$ ) are obtained with simultaneous saccharification and fermentation (SSF) ${ }^{28}$.

Neves et al. (2016) investigated cellulosic ethanol production from native as well as ethanol extracted SCB ${ }^{49}$. The extraction with ethanol was performed to reduce the total extractives content for removal of inhibitory compounds. They made use of 
steam explosion method with three different configurations for the pre-treatment of native and ethanol extracted $\mathrm{SCB}$; autohydrolysis and dilute acid hydrolysis with $\mathrm{H}_{2} \mathrm{SO}_{4}$ and $\mathrm{H}_{3} \mathrm{PO}_{4}$. The pre-treated SCB was subjected to enzymatic hydrolysis for glucose release using commercial cellulase preparation Cellic CTec2 followed by fermentation with an industrial strain of $S$. cerevisiae. Similar results were obtained for glucose recovery and ethanol production with three pre-treatment methods. The ethanol production in terms of titer and yield was better with SHF than SSF. The highest ethanol titer $(27.1 \mathrm{~g} / \mathrm{L})$ and yield $(0.47$ $\mathrm{g} / \mathrm{g}$ ) were obtained during SHF using SCB pre-treated by autohydrolysis. On the other hand, total reaction time was lower in SSF ( $48 \mathrm{~h}$ ) than SHF ( $84 \mathrm{~h}$ ) leading to high volumetric productivities. The maximum ethanol productivity was achieved $(0.58 \mathrm{~g} / \mathrm{L} . \mathrm{h})$ when SSF was carried out after pre-hydrolysis with a total processing time of $24 \mathrm{~h}$. Though ethanol extraction removed $80 \%$ of organic solvent extractable materials from $\mathrm{SCB}$, this extraction had no impact on ethanol production regardless of pre-treatment method and fermentation strategy. In a recent study, de Araujo Guilherme et al. (2019) employed different strategies to optimize the ethanol production from SCB through SSF in batch and fed-batch mode ${ }^{90}$. They made use of four pre-treatment methods (acid, alkali, hydrothermal and hydrogen peroxide) and four microbial strains for ethanol production. In addition, enzyme dose and inoculum size were optimized. The highest cellulose content of $65 \%$ was achieved with acid-alkali pre-treatment and was most favourable towards ethanol production. The synergistic effect of two pretreatment favoured removal of lignin and hemicellulose by acid and alkaline step, respectively. Further, the combined pretreatment resulted in reduction of crystallinity of cellulose. Among the four strains used, the maximum ethanol yield was obtained using $S$. cerevisiae PE-2 and cellulosic carbon after acid-alkali pre-treatment. The batch SSF process using optimized parameters (inoculum size: $1 \mathrm{~g} / \mathrm{L}$, enzyme dose: 15 FPU cellulase/g cellulose and initial cellulose: $6 \%$ ) resulted in an ethanol titer, yield and productivity of $31.5 \mathrm{~g} / \mathrm{L}, 0.47 \mathrm{~g} / \mathrm{g}$ and $1.75 \mathrm{~g} / \mathrm{L}$.h. The fed-batch cultivation with three time less enzyme dose in comparison to batch process yielded $29.8 \mathrm{~g} / \mathrm{L}$ in $40 \mathrm{~h}$ with $0.45 \mathrm{~g} / \mathrm{g}$ yield. To overcome the limitations of SSF, Liu et al. (2016) included pre-hydrolysis of alkali pre-treated SCB i.e. after $24 \mathrm{~h}$ of pre-hydrolysis at $50^{\circ} \mathrm{C}$, the temperature was reduced to $37^{\circ} \mathrm{C}$ and inoculated with yeast for SSF ${ }^{91}$. With this approach, they were able to enhance solid loading up to $36 \%$. The ethanol fermentations were conducted in batch and fedbatch mode with pre-hydrolysis SSF. The maximum ethanol titer of $66.9 \mathrm{~g} / \mathrm{L}$ was achieved with a conversion efficiency of $72.9 \%$ in $96 \mathrm{~h}$ in fed-batch mode with $30 \%(\mathrm{w} / \mathrm{v})$ loading. Despite much efforts, the use of SCB as feedstock for ethanol synthesis is still far from commercialisation due to expensive pre-treatments, moderate titers and low volumetric productivities 92,93 .

To incentivize $2 \mathrm{G}$ Ethanol sector, support and create a suitable ecosystem for setting up commercial projects and increasing Research \& Development, Government of India on 28-Feb-2019 launched the "Pradhan Mantri JI-VAN (Jaiv Indhan Vatavaran
Anukool Fasal Awashesh Nivaran) Yojana" as a tool to create 2G Ethanol capacity in the country and attract investments in this new sector. The said scheme has been notified on 08-Mar-2019 in Extraordinary Gazette of India. The scheme objective is to support 12 Commercial Scale and 10 demonstration scale 2G ethanol projects with a viability gap funding with a total financial outlay of ₹ 1969.50 crore for the period 2018-19 to 2023-24. Out of ₹ 1969.50 crore, ₹ 1800 crore has been allocated for supporting 12 commercial projects, ₹ 150 crore has been allocated for supporting 10 demonstration projects and remaining ₹ 19.50 crore will be provided to Centre for High Technology (CHT) as administrative charges.

\section{Xylitol}

Xylitol is a polyol with applications in the food, odontological, and pharmaceutical industries. Xylitol is a platform chemical and according to US Department of Energy, it is amongst the 12 renewable added-value chemicals which can be manufactured using biomass. Xylitol has been granted GRAS (Generally Regarded As Safe) status by US Food and Drug Administration for application in both food and beverage industries, a factor which will further stimulate its commercial growth. Xylitol has huge commercial potential and market is expected to reach $\$ 1.37$ billion by $2025^{27,94}$. Xylose to xylitol conversion is a single step reduction which can be carried out chemically or biochemically. The chemical route involves catalytic hydrogenation of purified xylose from hemicellulosic hydrolysates while biochemically, xylose is reduced to xylitol mediated by xylose reductase and $N A D(P) H$. The biological production of xylitol has received significant attention due to its sustainability and eco-friendly nature. On the other hand, chemical route is energy intensive, require extensive purification, suffers from low product recovery and catalyst deactivation making it expensive ${ }^{95,96}$. Significant research has been done in last two decades to enhance the economic viability of bioproduction of xylitol and to this end, hemicellulosic hydrolysate from different biomass rich in xylose including SCB has been utilized for bioproduction of xylitol by a number of research groups.

Our consortium worked towards xylitol production using SCB from Indian sugar mills. The xylose rich hemicellulosic hydrolysate for this purpose was provided by our industrial partner Nova Pangaea Technologies. We used two different yeast strains with GRAS status for biotransformation of xylose into xylitol; Yarrowia lipolytica and Pichia fermentans. Y. lipolytica is a non-conventional oleaginous yeast lacking the ability to grow on xylose, however, the cell mass of yeast can transform xylose into xylitol. The high cell density of yeast was accumulated on glucose/pure glycerol/crude glycerol followed by transformation of xylose into xylitol and the conversion yields obtained were $\geq 90 \%$. When pure xylose was replaced with hemicellulosic hydrolysate in optimized medium, the yield dropped to $54 \%{ }^{97}$ (Figure 4). The observed drop in yield might have been due to the inhibitors in hydrolysate which would have been overcome with suitable detoxification. Although this 
preliminary work was positive, more work is required to achieve superior performance. In another study ${ }^{98}$ (manuscript under review), a xylose eating and xylitol accumulating yeast $P$. fermentans was isolated. The wild type strain was subjected to random mutagenesis and a mutant strain outperforming wild type was identified. The culture medium was optimized using statistical method and the process was scaled up from shake flask $(250 \mathrm{~mL}$ with a working volume of $50 \mathrm{~mL}$ ) to bioreactor level $(2.5 \mathrm{~L}$ with a working volume of $1.0 \mathrm{~L})$. After media optimization, the mutant strain produced a maximum xylitol titer and yield of $70.5 \mathrm{~g} / \mathrm{L}$ and $0.49 \mathrm{~g} / \mathrm{g}$ respectively from pure xylose. While on xylose rich hydrolysate, the strain was able to accumulate $62.3 \mathrm{~g} / \mathrm{L}$ xylitol with conversion yield of $0.43 \mathrm{~g} / \mathrm{g}$. Upon scaling up using an optimized media composition, the xylitol titer and yield improved to $98.9 \mathrm{~g} / \mathrm{L}$ and $0.67 \mathrm{~g} / \mathrm{g}$, respectively with pure xylose. In case of hydrolysate, the xylitol concentration and conversion yield enhanced to $79 \mathrm{~g} / \mathrm{L}$ and 0.54 g/g respectively (Figure 5 ).

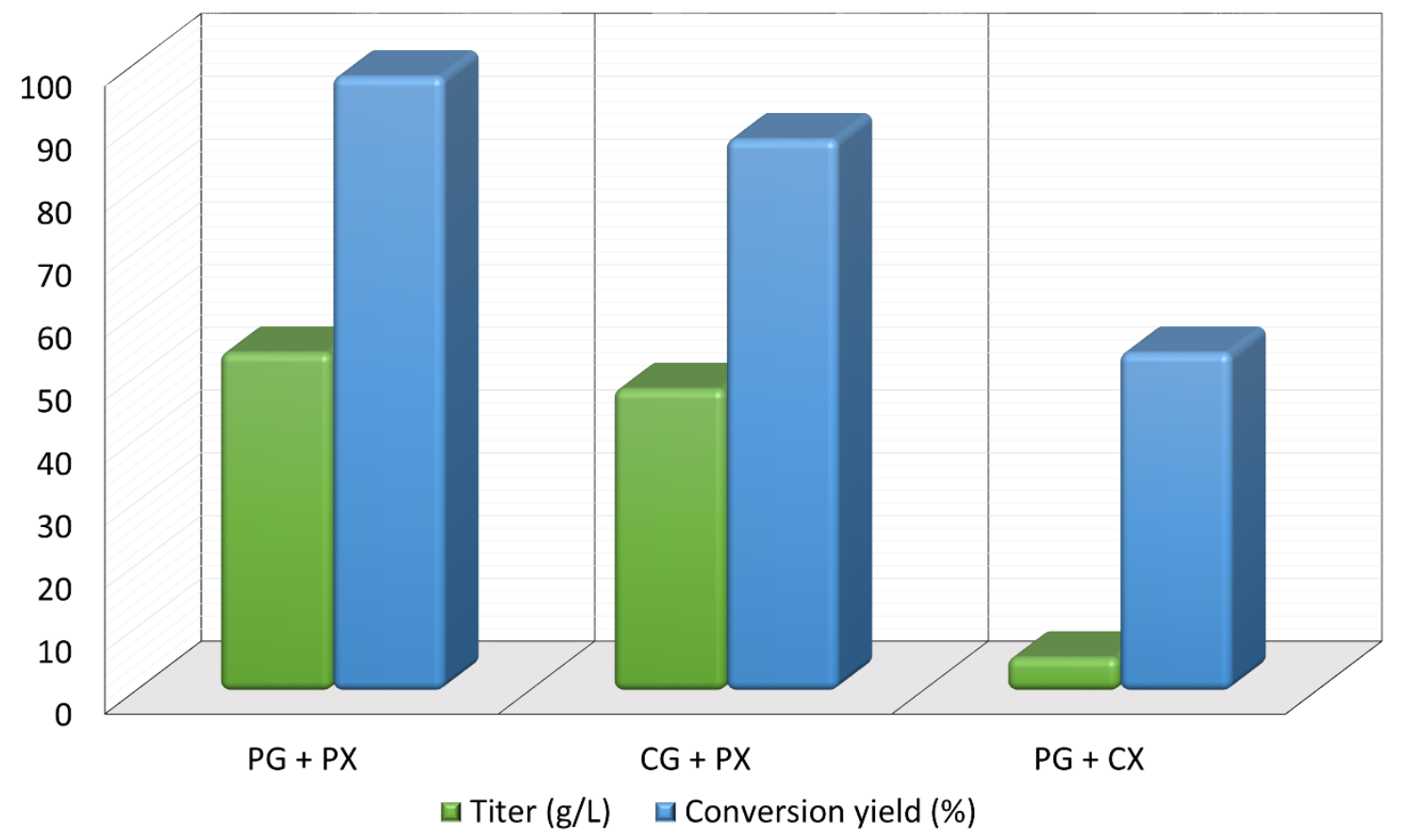

Figure 4: Xylitol production and yield from co-fermentation of glycerol and xylose by Y. lipolytica (PG: Pure glycerol; CG: Crude glycerol; PX: Pure xylose; CX: Crude xylose).

The integrated biorefineries for simultaneous synthesis of ethanol and xylitol could enhance the profitability of cellulosic ethanol production by 2.3 -fold ${ }^{94}$. Therefore, the co-production of ethanol and xylitol from cellulosic and hemicellulosic fractions has been attempted to improve the process economics of SCB-based biorefineries. Xylitol has higher market value than ethanol, therefore, an integrated SCB processing for co-production would create economic benefits making overall process feasible 99 . Two different approaches have been employed for the co-production; use of a single organism for two products; one strain for each metabolite. da Silva et al. (2015) and Dasgupta et al. (2017) used Kluyveromyces marxianus for co-production 95, 100. K.marxianus produced ethanol (titer: $12 \mathrm{~g} / \mathrm{L}$; yield: $0.22 \mathrm{~g} / \mathrm{g}$; productivity: $0.08 \mathrm{~g} / \mathrm{L} . \mathrm{h}$ ) from cellulosic hydrolysate. While with hemicellulosic hydrolysate, xylitol (titer: $9.4 \mathrm{~g} / \mathrm{L}$; yield: $0.40 \mathrm{~g} / \mathrm{g}$; productivity: $0.10 \mathrm{~g} / \mathrm{L} . \mathrm{h}$ ) was obtained as the main product with ethanol (1.31 $\mathrm{g} / \mathrm{L}$ ) as a by-product (da Silva et al. 2015). In a second approach, Castañón-Rodríguez et al. (2015) utilised two different yeasts, S. cerevisiae and C. tropicalis which are best known for their ability to ferment glucose and xylose to ethanol and xylitol, respectively ${ }^{101}$. These two yeast strains were co-cultured using simulated medium of SCB hydrolysate instead of separate fermentations for ethanol and xylitol. The best condition for coculture was sequential addition where fermentation was initiated with $S$. cerevisiae and $24 \mathrm{~h}$ later, C. tropicalis was inoculated. As a result, the glucose concentration reduced to a low level to allow efficient utilization of xylose. The fed-batch cultivation with sequential co-culture resulted in enhanced production of both metabolites, ethanol (titer: $19.5 \mathrm{~g} / \mathrm{L}$; yield: $0.44 \mathrm{~g} / \mathrm{g}$; productivity: $0.87 \mathrm{~g} / \mathrm{L} . \mathrm{h}$ ) and xylitol (titer: $10.0 \mathrm{~g} / \mathrm{L}$; yield: $0.57 \mathrm{~g} / \mathrm{g}$; productivity: $0.27 \mathrm{~g} / \mathrm{L} . \mathrm{h}$ ). In another study by Unrean and Ketsub, 2018, S. cerevisiae and C. tropicalis were cultured separately for production of ethanol and xylitol. The fed-batch cultivation resulted in highest concentrations of ethanol by $S$. cerevisiae and xylitol by C.tropicalis at $56.1 \mathrm{~g} / \mathrm{L}$ and $24 \mathrm{~g} / \mathrm{L}$ with product yields of 0.44 and $0.50 \mathrm{~g} / \mathrm{g}$ respectively.

Significant research has been done in last decades on bioproduction of xylitol and substantial improvement in titer, yield and productivity of xylitol has been achieved using metabolic and process engineering approaches. Despite all these, the bioprocess is still far from industrial level production. Even today, the chemical route for xylitol production remains 


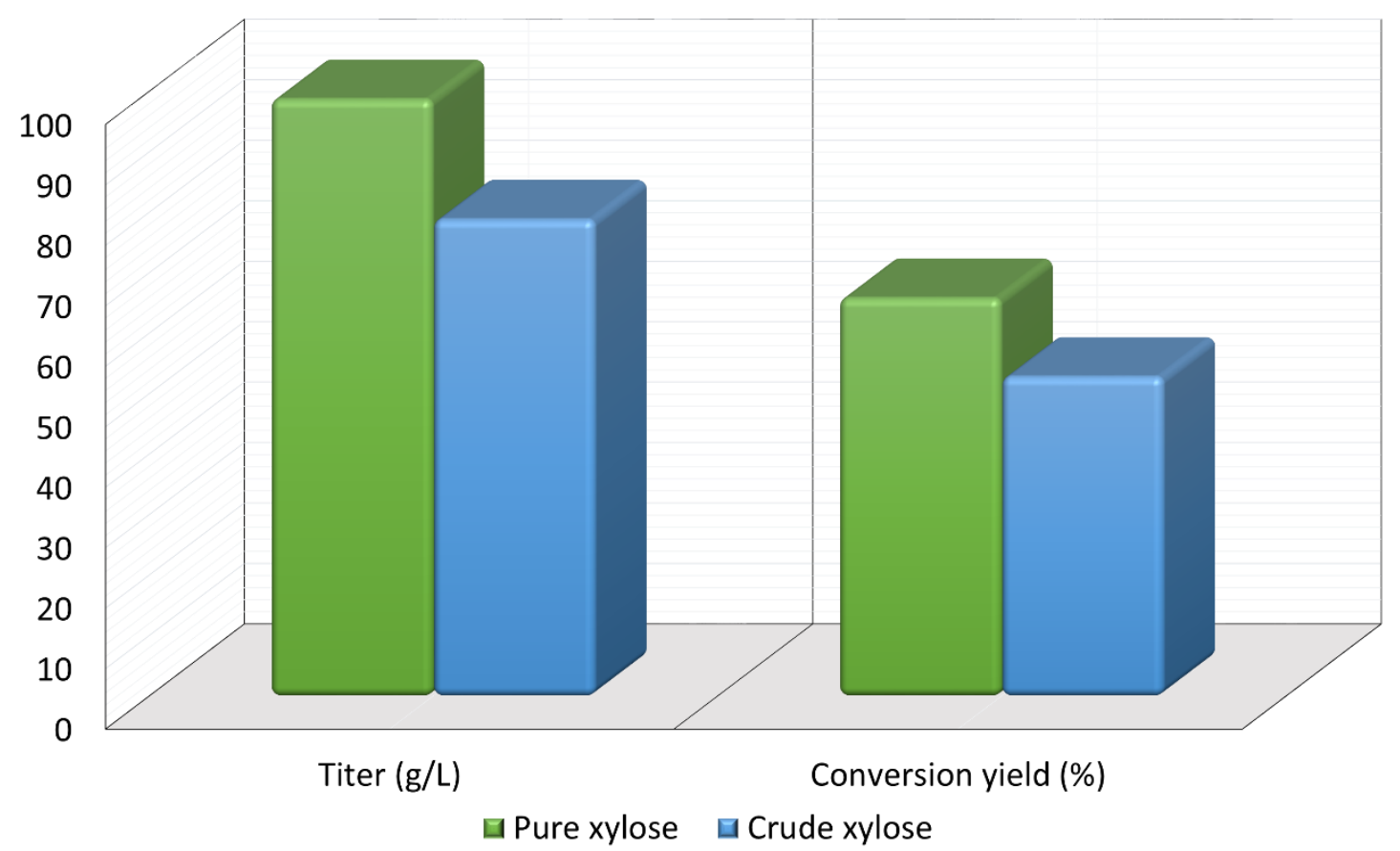

Figure 5: Comparison of xylitol accumulation by newly isolated yeast $P$. fermentans using pure and crude xylose.

the dominant one 94,96 . According to a simulation study by Mountraki et al. (2017), the amount of xylitol crystals which can be obtained from $1 \mathrm{~kg}$ of xylose via chemical and biotechnological routes were 0.87 and $0.73 \mathrm{~kg}$, respectively 102 . In order to make the biological route competitive to its chemical counterpart, several hurdles need to be overcome to cut down the high capital and operational cost of various steps such as pre-treatment, detoxification, fermentation and downstream processing. Table 6 summarises the xylitol production from SCB by different microorganisms and the comparison reveals that our results outperformed other previous reports, making it competitive. Most of the studies in Table 6 have detoxified the hydrolysate using methods such as over liming, activated charcoal, ion exchange resin adsorption treatment or a combination of these for improving fermentation performance. Detoxification adds to the operational costs and may also lead to loss of sugars. Thus, a cost effective and convenient pre-treatment with minimum or no release of inhibitors eliminating detoxification step along with efficient recovery of xylitol is highly desirable. This in combination with design of hyper and robust xylitol producer with aid of advanced metabolic engineering and synthetic biology, process design, intensification and integration with sugar mills can enhance the commercial feasibility of xylitol production at bulk level.

\section{Succinic acid}

According to US Department of Energy, SA is a top platform chemical which can be produced from biomass. The presence of two carboxyl groups makes it a versatile precursor molecule for manufacturing a large number of industrially important products such as tetrahrdrofuran, 1,4-butanediol, $\gamma$ butyrolactone, adipic acid, aliphatic esters etc ${ }^{103}$. The global production of SA was reported to be 50,000 metric ton in 2016 and is expected to be double by $2025{ }^{104}$. Due to growing interest towards greener production of chemicals in recent times, there has been paradigm shift from petrochemical synthesis towards bio-based production of SA, a potential alternative. The bio-based SA production also contributes to reduction in carbon emission as it requires carbon dioxide, a primary greenhouse gas, as a co-substrate. The commercial potential of bioproduction of SA is impeded by its higher cost in comparison to chemically synthesized SA 105,106 . The cost of production can be reduced by the use of crude renewable sources such as SCB. There are handful of studies using SCB as feedstock for bioproduction of SA (Table 7). Borges and Pereira (2011) used Actinobacillus succinogenes for SA production from xylose ${ }^{107}$. The culture medium was optimized using Central Composite Rotational Design with four variables $\mathrm{NaHCO}_{3}$, $\mathrm{MgSO}_{4}$, yeast extract and $\mathrm{KH}_{2} \mathrm{PO}_{4}$. The optimized medium composition resulted in a SA production of $14.2 \mathrm{~g} / \mathrm{L}$, yield of $0.64 \mathrm{~g} / \mathrm{g}$ and productivity of $0.67 \mathrm{~g} / \mathrm{L}$.h. When pure xylose was replaced with SCB hemicellulosic hydrolysate containing $52 \mathrm{~g} / \mathrm{L}$ xylose, SA accumulated was $22.5 \mathrm{~g} / \mathrm{L}$ with yield and productivity of $0.43 \mathrm{~g} / \mathrm{g}$ and $1.01 \mathrm{~g} / \mathrm{L}$.h. Though all the xylose was consumed, and production rate was faster, the conversion efficiency was lower in comparison to pure xylose, probably due to presence of fermentation inhibitors. Xi et al. (2013) combined acid hydrolysis and ultrasonic pre-treatment which improved the sugar yield by $29.5 \% 108$. The highest sugar concentration of $43.9 \mathrm{~g} / \mathrm{L}$ was obtained when ultrasonication was carried out for 40 minutes in comparison to $33.9 \mathrm{~g} / \mathrm{L}$ without ultrasonic pretreatment. This allowed maximum use of hemicellulosic carbon and reduced the yeast extract requirement by $60 \%$. 
Table 6: Biological production of xylitol from sugarcane bagasse hemicellulosic hydrolysate

\begin{tabular}{|c|c|c|c|c|c|c|c|}
\hline Organism & Pre-treatment & Detoxification method & $\begin{array}{l}\text { Fermentation } \\
\text { mode }\end{array}$ & $\begin{array}{l}\text { Titer } \\
(\mathrm{g} / \mathrm{L})\end{array}$ & $\begin{array}{l}\text { Yield } \\
\text { (g/g) }\end{array}$ & $\begin{array}{l}\text { Productivity } \\
\text { (g/L. h) }\end{array}$ & Reference \\
\hline $\begin{array}{l}\text { Candida guilliermondii FTI } \\
20037\end{array}$ & Acid hydrolysis & $\begin{array}{l}\text { pH adjustment, activated } \\
\text { charcoal, vacuum filtration, }\end{array}$ & Batch & 36.3 & 0.64 & 0.76 & $\begin{array}{l}\text { Rodrigues et al., } \\
2003^{109}\end{array}$ \\
\hline $\begin{array}{l}\text { Candida guilliermondii FTI } \\
20037\end{array}$ & Acid hydrolysis & $\begin{array}{l}\mathrm{pH} \text { adjustment, activated } \\
\text { charcoal }\end{array}$ & $\begin{array}{l}\text { Batch; } \\
\text { Immobilized }\end{array}$ & 47.5 & 0.81 & 0.40 & $\begin{array}{l}\text { Carvalho et al., } \\
2004^{110}\end{array}$ \\
\hline Candida tropicalis & Acid hydrolysis & $\begin{array}{l}\text { Activated charcoal, vacuum } \\
\text { filtration, ion exchange }\end{array}$ & Batch & 19.5 & 0.65 & - & Rao et al., $2006^{111}$ \\
\hline Candida tropicalis $\mathrm{JH} 030$ & Acid hydrolysis & $\mathrm{pH}$ adjustment & Batch & 12.5 & 0.51 & - & Huang et al., $2011^{112}$ \\
\hline Debaryomyces hansenii & $\begin{array}{l}\text { Steam explosion, Acid } \\
\text { hydrolysis }\end{array}$ & Activated charcoal & Batch & 13.8 & 0.69 & 0.28 & Prakash et al., $2011^{113}$ \\
\hline $\begin{array}{l}\text { Candida guilliermondii } \\
\text { FTI20037 }\end{array}$ & Acid hydrolysis & $\begin{array}{l}\text { Vacuum concentration, } \mathrm{pH} \\
\text { adjustment, activated charcoal }\end{array}$ & Batch & 36.1 & 0.75 & 70.4 & $\begin{array}{l}\text { Hernández-Pérez et } \\
\text { al., } 2016^{85}\end{array}$ \\
\hline Candida tropicalis & $\begin{array}{l}\text { Hot water } \\
\text { autohydrolysis }\end{array}$ & $\begin{array}{l}\text { Vacuum concentration, } \\
\text { overliming, activated charcoal }\end{array}$ & Batch & 32.0 & 0.46 & 0.27 & Vallejos et al., $2016^{114}$ \\
\hline $\begin{array}{l}\text { Candida guilliermondii } \\
\text { FTI20037 }\end{array}$ & Acid hydrolysis & $\begin{array}{l}\text { Vacuum concentration, } \mathrm{pH} \\
\text { adjustment, activated charcoal }\end{array}$ & Batch & 41.8 & 0.66 & 0.29 & $\begin{array}{l}\text { de Arruda et al., } \\
2017^{115}\end{array}$ \\
\hline Yarrowia lipolytica & Hydrothermal & $\mathrm{pH}$ adjustment & Batch & 5.4 & 0.54 & 0.11 & Prabhu et al., $2020 c^{97}$ \\
\hline Pichia fermentans & Hydrothermal & $\mathrm{pH}$ adjustment & Batch & 79.0 & 0.54 & 0.47 & Prabhu et al., $2020 a^{98}$ \\
\hline \multicolumn{8}{|c|}{ Co-production of xylitol and ethanol } \\
\hline $\begin{array}{l}\text { Kluyveromyces marxianus } \\
\text { ATCC } 36907\end{array}$ & Acid-alkaline hydrolysis & Overliming & Batch & $\begin{array}{l}9.4 \\
(12.0)\end{array}$ & $\begin{array}{l}0.40 \\
(0.22) \\
\end{array}$ & $\begin{array}{l}0.10 \\
(0.08)\end{array}$ & da Silva et al., $2015^{100}$ \\
\hline $\begin{array}{l}\text { Saccharomyces cerevisiae/ } \\
\text { Candida tropicalis }\end{array}$ & - & $\mathrm{pH}$ adjustment & Fed-Batch & $\begin{array}{l}10.0 \\
(19.5)\end{array}$ & $\begin{array}{l}0.57 \\
(0.44) \\
\end{array}$ & $\begin{array}{l}0.27 \\
(0.87) \\
\end{array}$ & $\begin{array}{l}\text { Castañón-Rodríguez } \\
\text { et al., } 2015^{101}\end{array}$ \\
\hline $\begin{array}{l}\text { Kluyveromyces marxianus } \\
\text { IIPE453 }\end{array}$ & $\begin{array}{l}\text { Acid and steam } \\
\text { hydrolysis }\end{array}$ & Overliming & Batch & $\begin{array}{l}11.1 \\
(21.6)\end{array}$ & $\begin{array}{l}0.32 \\
(0.45)\end{array}$ & $\begin{array}{l}0.19 \\
(0.90)\end{array}$ & $\begin{array}{l}\text { Dasgupta et al., } \\
2017^{95}\end{array}$ \\
\hline $\begin{array}{l}\text { Saccharomyces cerevisiae/ } \\
\text { Candida tropicalis }\end{array}$ & Acid hydrolysis & $\mathrm{pH}$ adjustment & Fed-Batch & $\begin{array}{l}24.0 \\
(56.1)\end{array}$ & $\begin{array}{l}0.50 \\
(0.44)\end{array}$ & $0.25(0.58)$ & $\begin{array}{l}\text { Unrean \& Ketsub, } \\
2018^{99}\end{array}$ \\
\hline
\end{tabular}

a - The value in parenthesis refer to ethanol production from cellulosic hydrolysate. 
The batch fermentation of non-detoxified hemicellulosic hydrolysate containing $22.5 \mathrm{~g} / \mathrm{L}$ xylose, $3.6 \mathrm{~g} / \mathrm{L}$ glucose and 3.9 $\mathrm{g} / \mathrm{L}$ arabinose was performed in a bioreactor. All the sugars were consumed, and SA achieved at the end of fermentation was $23.7 \mathrm{~g} / \mathrm{L}$. The yield and productivity were $0.77 \mathrm{~g} / \mathrm{g}$ and 0.99 $\mathrm{g} / \mathrm{L}$.h. The hydrolysate contained $2.84 \mathrm{~g} / \mathrm{L}$ total soluble phenolic compounds, $0.42 \mathrm{~g} / \mathrm{L} \mathrm{HMF}$, and $0.71 \mathrm{~g} / \mathrm{L}$ furfural. Despite this, surprisingly, the results obtained with non-detoxified hydrolysate were better than detoxified one. The SA titer and yield achieved were 20.9 and $20.2 \%$ higher in comparison to detoxified hydrolysate showing detoxification was not required. No specific explanation was offered.

In another study by Chen et al. (2016), SCB-based SA production by $A$. succinogenes was evaluated ${ }^{116}$. They employed two different pre-treatment methods for SCB with different concentrations of acid/alkali and found that alkali pretreatment was better than its acid counterpart. The lignin removal was more than $90 \%$ with $\mathrm{NaOH}$ treatment, while in case of $\mathrm{H}_{2} \mathrm{SO}_{4}$ treatment, it was between $40-70 \%$. The best results were obtained at $0.25 \mathrm{M} \mathrm{NaOH}$ with cellulose and hemicellulose retention of 97.9 and $87.3 \%$, respectively, and lignin removal of $93.3 \%$. The composition of enzyme cocktail was optimized using an orthogonal design and the optimal conditions for saccharification of pre-treated SCB was 15, 9, 0.2 and $20 \% \mathrm{v} / \mathrm{w}$ biomass of cellulase, xylanase, glucanase and pectinase concentration, respectively. This optimal cocktail yielded a reducing sugar concentration of $55 \mathrm{~g} / \mathrm{L}$ with glucose and xylose in ratio of 3:1. The fed-batch cultivation was carried out using an initial reducing sugar concentration of $55 \mathrm{~g} / \mathrm{L}$ (41 $\mathrm{g} / \mathrm{L}$ glucose \& $14 \mathrm{~g} / \mathrm{L}$ xylose) and culture was fed when sugar level dropped below $20 \mathrm{~g} / \mathrm{L}$. At the end of the experiment, 70.8 $\mathrm{g} / \mathrm{L}$ of SA accumulated with a yield and productivity of $0.82 \mathrm{~g} / \mathrm{g}$ and $1.42 \mathrm{~g} / \mathrm{L} . \mathrm{h}$. They also conducted repeated batch fermentations using cell immobilized on surface of SCB residue (SBR) after alkaline pre-treatment and enzymatic hydrolysis. Three batches were performed and at the end of each batch fermentation, spent media was pumped out and fresh medium was added for cell growth and SA production. $\mathrm{NaHCO}_{3}$ was used to modulate $\mathrm{pH}$ and served as a source of $\mathrm{CO}_{2}$. The sugar consumption profile and SA production in all the three batches were similar. The amount of sugars consumed, and SA synthesized after three batches in a total time of $64 \mathrm{~h}$ was 149 and $120 \mathrm{~g} / \mathrm{L}$. The overall yield and productivity were $0.81 \mathrm{~g} / \mathrm{g}$ and $1.65 \mathrm{~g} / \mathrm{L}$.h. Acetic acid was obtained as the by-product in all the experiments $(4-10 \mathrm{~g} / \mathrm{L})$.

Bacteria are extremely sensitive towards low $\mathrm{pH}$ and require moderate $\mathrm{pH}$ for its growth, resulting in the consumption of large quantities of neutralizing agent that affects the productivity cost ${ }^{117}$. Further at neutral $\mathrm{pH}, \mathrm{SA}$ is obtained in the form of succinate salts and needs an additional step of acidification to bring it back to acid form leading to accumulation of by-products such as gypsum, in-turn making the downstream process more critical. This problem can be resolved by carrying out the fermentation at low $\mathrm{pH}$ value ${ }^{118}$. Obtaining SA in unionized form will simplify the downstream processing and lead to an economical process as it will avoid neutralization during fermentation and acidification during product recovery ${ }^{104}$.Yeasts are potential host to produce organic acid because of their high tolerance to low $\mathrm{pH}$ and are naturally predisposed to grow under low pH, below 4119 . Yarrowia lipolytica is an oleaginous and non-conventional yeast and excellent cell factory for synthesizing a large variety of commercially important products ${ }^{120}$. It has the amazing ability to grow perfectly well over a wide $\mathrm{pH}$ range without significant change in growth parameters ${ }^{121}$. In a recent report by Ong et al. (2019), feasibility of SA production from co-fermentation of glucose and xylose by $Y$. lipolytica was investigated ${ }^{122}$. They utilised pure as well as crude glucose and xylose from SCB as feedstock. To maximize sugar release from pre-treated SCB, enzymatic hydrolysis was optimized through three parameters: $\mathrm{pH}$, temperature and enzyme dosage. They reported $33.2 \mathrm{~g} / \mathrm{L}$ SA by $Y$. lipolytica using SCB hydrolysate containing $47.3 \mathrm{~g} / \mathrm{L}$ glucose and $20.2 \mathrm{~g} / \mathrm{L}$ xylose during bioreactor cultivation. Glucose was completely consumed by the yeast, however, large fraction of xylose remained unutilized (50-70\%). Our consortium also produced SA from SCB hemicellulosic hydrolysate by $Y$. lipolytica without the control of $\mathrm{pH}^{123}$. The yeast can utilize a variety of carbon sources but lacks the ability to metabolize xylose. $Y$. lipolytica was engineered for xylose assimilation and SA production. The batch cultivation of recombinant strain in bioreactor resulted in SA titer of $11.2 \mathrm{~g} / \mathrm{L}$ with the yield of $0.18 \mathrm{~g} / \mathrm{g}$. The experiment was repeated with crude xylose $(40 \mathrm{~g} / \mathrm{L})$ rich hydrolysate derived from SCB. Hydrolysate after pre-treatment often contains inhibitors which can negatively impact the performance of microorganisms. The cell growth was unaffected as biomass yield was similar in both the cases. The strain accumulated 5.6 $\mathrm{g} / \mathrm{L}$ of SA titer with the yield of $0.14 \mathrm{~g} / \mathrm{g}$ (Figure 7 ). Acetic acid was obtained as the major product at higher quantities $(8.3 \mathrm{~g} / \mathrm{L})$ than the desired product SA. Further work to divert produced acetic acid towards SA is underway.

It is important to discuss two studies in recent times related to cost analysis for SA production from SCB. The sugar yield during pre-treatment has significant impact on commercial viability of LCB-based biorefineries. Nieder-Heitmann et al. (2020) investigated profitability of different pre-treatment methods for SCB through simulation work using Aspen Plus 124. They screened available pre-treatment technologies, identified nine methods which were simulated and compared for the coproduction of succinic acid and electricity in a SCB and trash biorefinery. The nine pre-treatment methods were as follows: dilute acid treatment (DAT) with enzymatic hydrolysis (EH); DAT without $\mathrm{EH} ; \mathrm{NaOH}$ with $\mathrm{EH}$; organosolv with $\mathrm{EH}$; ammonia fibre expansion with EH; steam explosion (STEX) with EH; STEX with $\mathrm{SO}_{2}$ and $\mathrm{EH}$; STEX with $\mathrm{NaOH}$ and $\mathrm{EH}$; wet oxidation with $\mathrm{EH}$. Except organosolv and wet oxidation, all other pre-treatment methods were found to be profitable. The most profitable was steam explosion with SA yield, capital cost and internal rate of return (IRR) of $45.7 \mathrm{~kg} \mathrm{SA} / 100$ ton dry mass, \$ 384.7 million and $28 \%$ respectively. The two challenges identified were proper mixing for efficient mass and heat transfer during pretreatment and scale up of $\mathrm{EH}$ to commercial level. 


\section{ARTICLE}

Table 7:Bioproduction of succinic acid from SCB

\begin{tabular}{|c|c|c|c|c|c|c|c|c|}
\hline Organism & Pre-treatment & Feedstock & $\begin{array}{l}\text { Detoxification } \\
\text { method }\end{array}$ & $\begin{array}{l}\text { Fermentation } \\
\text { mode }\end{array}$ & $\begin{array}{l}\text { Titer } \\
(\mathrm{g} / \mathrm{L})\end{array}$ & $\begin{array}{l}\text { Yield } \\
\text { (g/g) }\end{array}$ & $\begin{array}{l}\text { Productivity } \\
\text { (g/L. h) }\end{array}$ & Reference \\
\hline $\begin{array}{l}\text { Actinobacillus } \\
\text { succinogenes }\end{array}$ & Acid hydrolysis & Hemicellulosic hydrolysate & $\mathrm{pH}$ adjustment & Batch & 22.5 & 0.43 & 1.01 & $\begin{array}{l}\text { Borges \& Pereira, } \\
2011^{107}\end{array}$ \\
\hline $\begin{array}{l}\text { Actinobacillus } \\
\text { succinogenes }\end{array}$ & $\begin{array}{l}\text { Acid hydrolysis } \\
\text { with } \\
\text { ultrasonication }\end{array}$ & Hemicellulosic hydrolysate & $\mathrm{pH}$ adjustment & Batch & 23.7 & 0.77 & 0.99 & Xi et al., $2013^{108}$ \\
\hline $\begin{array}{l}\text { Actinobacillus } \\
\text { succinogenes }\end{array}$ & Alkali hydrolysis & $\begin{array}{l}\text { Cellulosic/hemicellulosic } \\
\text { hydrolysate }\end{array}$ & $\mathrm{pH}$ adjustment & Fed-Batch & 70.8 & 0.82 & 1.42 & Chen et al., $2016^{116}$ \\
\hline $\begin{array}{l}\text { Actinobacillus } \\
\text { succinogenes }\end{array}$ & Alkali hydrolysis & $\begin{array}{l}\text { Cellulosic/hemicellulosic } \\
\text { hydrolysate }\end{array}$ & $\mathrm{pH}$ adjustment & $\begin{array}{l}\text { Repeated- } \\
\text { Batch }\end{array}$ & 120 & 0.81 & 1.65 & Chen et al., $2016^{116}$ \\
\hline Yarrowia lipolytica & Alkali hydrolysis & $\begin{array}{l}\text { Cellulosic/hemicellulosic } \\
\text { hydrolysate }\end{array}$ & $\mathrm{pH}$ adjustment & Batch & 33.2 & 0.58 & 0.33 & Ong et al., $2019^{122}$ \\
\hline Yarrowia lipolytica & Hydrothermal & Hemicellulosic hydrolysate & $\mathrm{pH}$ adjustment & Batch & 5.6 & 0.14 & 0.093 & $\begin{array}{l}\text { Prabhu et al., } \\
2020 b^{123}\end{array}$ \\
\hline
\end{tabular}




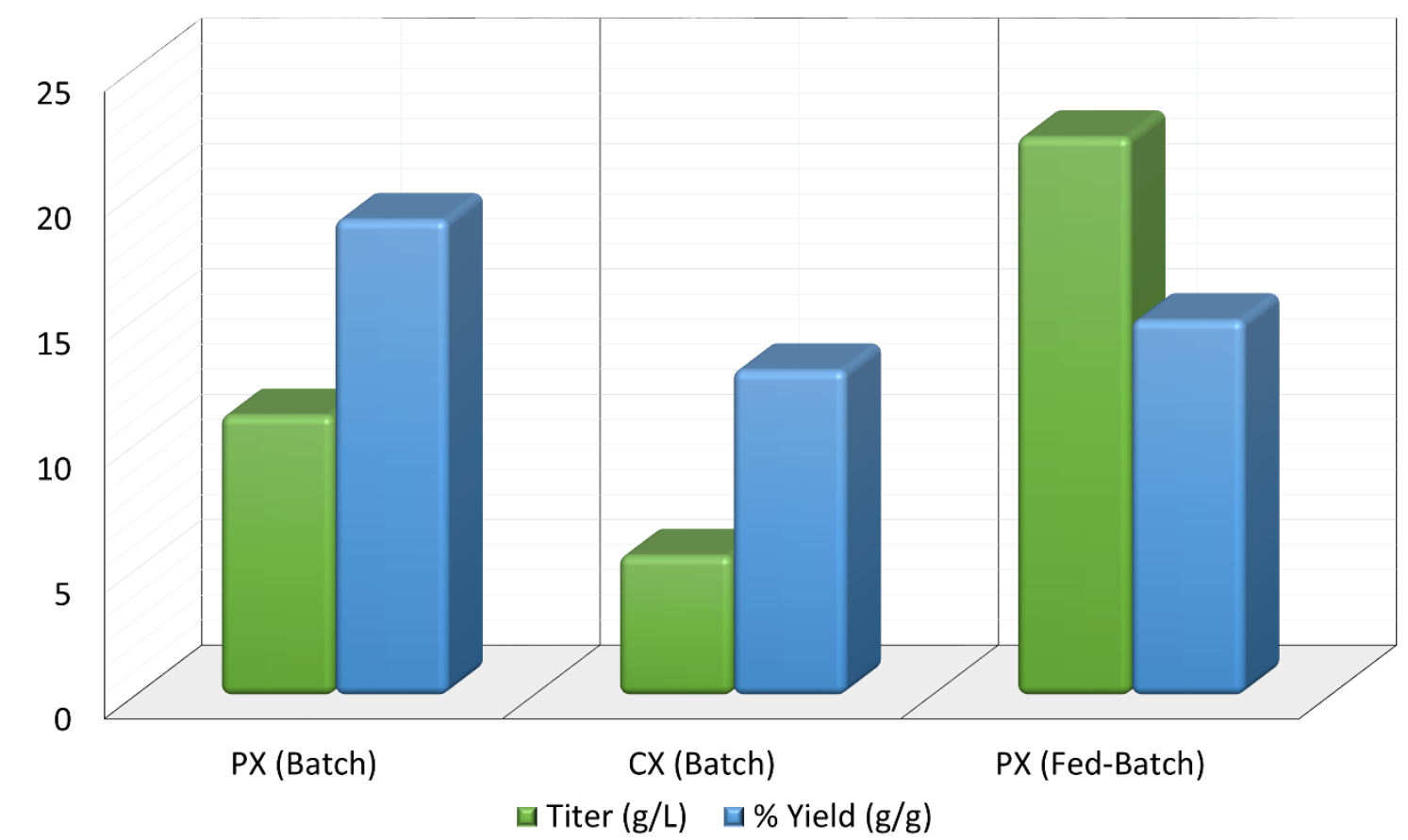

Figure 6: Succinic acid production from pure and crude xylose by engineered $Y$. lipolytica during batch and fed-batch fermentations (PX: Pure xylose; CX: Crude xylose).

In another study, Klein et al. (2017) carried out simulation studies using Aspen Plus for integration of SA production from SCB to optimized SCB biorefinery with the production of first generation (1G) ethanol and electricity ${ }^{125}$. SCB was pre-treated using dilute $\mathrm{H}_{2} \mathrm{SO}_{4}$ and hemicellulosic hydrolysate ( $\mathrm{C} 5$ liquor) obtained was fermented to SA by wild type $A$. succinogenes after detoxification. The cellulignin fraction was utilized for electricity generation via CHP. The downstream step was designed and simulated based on literature data and resulted in recovery of SA up to $99 \%$. The calculated cost of SA production was $\$ 2.32 / \mathrm{kg}$ with sugarcane and capital cost being the major contributors. The calculated cost was similar to sugar-based SA production, $\$ 2.26 / \mathrm{kg}$ SA from sucrose. Further, the internal rate of return for integrated SA biorefinery (15.8\%) was lower than ethanol distillery (17\%). The $1 \mathrm{G}$ ethanol production is a mature and well established technology, on the other hand, 2G SA production is in infancy and an emerging technology with lots of scope for improvement at process as well as at strain level.

\section{Lactic acid (LA)}

LA is an industrially important chemical and has been included in the revised list of platform chemicals prepared by US Department of Energy 126. LA finds its applications in food, chemical, textile, pharmaceutical, and other industries 127, 128 and its worldwide demand is estimated at 130,000-150,000 tonne per year ${ }^{129}$. LA can be produced commercially either chemically or by fermentation. Chemical synthesis results in a racemic mixture of two isomers, whereas microbial fermentation can lead to an optically pure isomer depending on the strain, raw materials and conditions used during fermentation ${ }^{130,131}$. Most of the LA ( 90\%) worldwide comes from microbial fermentation of carbohydrates and remaining by chemical synthesis ( $10 \%)$. The major fermentative manufacturers of LA are Nature Works LLC (USA), Purac (Netherlands) and Galactic (Belgium) ${ }^{132}$.

LA has also been receiving great attention as a feedstock for the manufacture of polylactic acid (PLA), a biodegradable polymer used as a raw material in packaging as well as fibres and foams. At industrial scale, PLA production is considered a relatively immature technology as compared with petrochemical raw materials, mainly due to the high production cost of LA which is the raw material for PLA. The high costs of LA production are due to expensive sugar \& nitrogen sources required for fermentation along with the downstream recovery and purification process. A major concern in LA fermentation is to reduce the cost of the raw materials. This problem can be resolved through fermentative production of LA from low cost materials such as wastes from agricultural and agro-industrial residues. SCB can be the choice of raw material for LA production due to low cost and well-established supply chain. However, most starchy and lignocellulose materials must be pre-treated by physicochemical and enzymatic methods as discussed in earlier sections. Also, LA from SCB will be economically attractive and competitive with LA production from pure sugars, if their productivities and yields are similar to pure sugar fermentations. It can only be accomplished when enzymatic liquefaction is performed at a high solid loading of pre-treated lignocellulosic biomass with uncompromised and concentrated sugar yields. Some of the factors that have a direct impact on enzyme hydrolysis are type of pre-treatment 133,134 origin of the cellulases complex and accessory enzymes 
associated with it, $\mathrm{pH}$, water availability and substrate feeding strategies ${ }^{135,136 .}$

LA production from SCB reported in the literature is summarised in Table 8. Patel et al. (2005) used Bacillus sp. 36D1 (isolate) for LA production. Batch SSF of $20 \mathrm{~g} / \mathrm{L}$ Solka Floc (commercial cellulose powder) with $10 \mathrm{FPU}$ of Spezyme CE/g cellulose were carried out for $96 \mathrm{~h}$ by varying $\mathrm{pH}$ ( 4.5 to 7 at 50 ${ }^{\circ} \mathrm{C}$ ) and temperature (30 to $60{ }^{\circ} \mathrm{C}$ at $\left.\mathrm{pH} 5\right){ }^{137}$. Volumetric productivity of $L A$ was optimal between fermentation $\mathrm{pH}$ values of 4.5 and 5.5 at $50{ }^{\circ} \mathrm{C}$. At a constant $\mathrm{pH}$ of 5 , LA titer of $18.3 \mathrm{~g} / \mathrm{L}$ with maximal LA volumetric productivity of $0.17 \mathrm{~g} / \mathrm{L} / \mathrm{h}$ was observed at $55{ }^{\circ} \mathrm{C}$ with $\mathrm{L}(+)$ isomer optical purity more than 95 $\%$. Further, they also investigated the co-fermentation of cellulose-derived glucose and sugarcane bagasse hemicellulose derived xylose simultaneously (SSCF). In a batch SSCF of $40 \%$ acid pre-treated hemicellulose hydrolysate (over-limed) and 20 $\mathrm{g} / \mathrm{L}$ Solka Floc cellulose, Bacillus sp. 36D1 produced about $35 \mathrm{~g} / \mathrm{L}$ LA in about $144 \mathrm{~h}$ with $15 \mathrm{FPU}$ of Spezyme CE/g cellulose.

To improve LA titer and productivity, Adsul et al. (2007) have used steam and alkali pre-treated SCB at higher solid loading and Lactobacillus delbrueckii mutant Uc- ${ }^{138}$. Batch SSF of 80 $\mathrm{g} / \mathrm{L}$ pre-treated SCB was conducted using a cellulase preparation (10 FPU per $\mathrm{g}$ of pre-treated SCB) derived from a mutant strain of Penicillium janthinellum. The LA titer of $67 \mathrm{~g} / \mathrm{L}$ was obtained in $96 \mathrm{~h}$ from steam-alkali pre-treated SCB. In another study, Van der Pol et al. (2016) employed multiple strategies for optimization of batch SSF of SCB obtained after acid pre-treatment and steam explosion ${ }^{139}$. They have investigated whether furfural addition (one of the inhibitors generated during pre-treatment) to precultures of Bacillus coagulans had beneficial effect on LA fermentation of pretreated and enzyme hydrolysed SCB. The preculture was cultivated in PYPD medium with $1 \mathrm{~g} / \mathrm{L}$ furfural. The pre-treated SCB solid fraction was hydrolysed with either liquid fraction obtained from pre-treatment of SCB or demineralized water. Pre-treated SCB was hydrolysed with the enzyme cocktail GC220 and fermented by the B.coagulans DSM 2315 at pH 5.8 and $50{ }^{\circ} \mathrm{C}$. For batch SSF of SCB with liquid fraction from pretreatment of SCB, LA titer of $74.6 \mathrm{~g} / \mathrm{L}$ and productivity of 0.92 $\mathrm{g} / \mathrm{L} / \mathrm{h}$ was obtained for preculture in PYPD medium with furfural as compared to LA titer of $64.1 \mathrm{~g} / \mathrm{L}$ and productivity of 0.78 $\mathrm{g} / \mathrm{L} / \mathrm{h}$ for preculture in PYPD medium. It was found that precultivation in the presence of furfural was beneficial for LA fermentation. For batch SSF of pre-treated SCB, solid in water and preculture in PYPD medium with furfural, the LA productivity increased to $1.14 \mathrm{~g} / \mathrm{L} / \mathrm{h}$ with $70.4 \mathrm{~g} / \mathrm{L}$ of LA. The better productivity in latter case was due to reduction lag phase from $40 \mathrm{~h}$ to $32 \mathrm{~h}$.

Increasing the sugar concentration in hydrolysates can improve the productivity and yield of fermentation products. To achieve higher sugar concentrations in SCB hydrolysate, evaporation after hydrolysis or pre-treatment have been exploited as strategies. Peng et al. (2014) concentrated enzyme hydrolysate of acid-alkali treated SCB. In their fed-batch fermentation experiments, $\mathrm{L}(+) \mathrm{LA}$ titer of $185 \mathrm{~g} / \mathrm{L}$ with productivity of 1.93 $\mathrm{g} / \mathrm{L} / \mathrm{h}$ was achieved with Bacillus sp. P38. In another study, de Oliveira et al. (2019) concentrated the hemicellulosic hydrolysate after acid pre-treatment of SCB by five times ${ }^{131}$. For B.coagulans fermentation, $\mathrm{L}(+) \mathrm{LA}$ titer of $55.9 \mathrm{~g} / \mathrm{L}$ with a yield of $0.87 \mathrm{~g} / \mathrm{g}$ and productivity of $1.7 \mathrm{~g} / \mathrm{L} / \mathrm{h}$ was obtained.

A range of bacterial strains such as Lactobacillus delbreuckii, Lactobacillus pentosus, Bacillus sp. and B.coagulans have been reported for LA fermentation (Table 8). The optimal growth conditions for these bacteria are spread over the temperature range of $35-50{ }^{\circ} \mathrm{C}$, but around neutral $\mathrm{pH}$. The enzymatic hydrolysis conditions required to produce sugar rich hydrolysates however require radically different conditions, namely, temperature in the range of $45-55{ }^{\circ} \mathrm{C}$ and $\mathrm{pH}$ in the range of 4.5-5.5. Therefore, SSF as an approach for LA production from SCB would not be a feasible option as it compromises the operating parameters such as temperature and $\mathrm{pH}$ for either the hydrolysis stage or the fermentation stage. Hence, SHF can be a preferred approach over SSF especially for LA fermentation.

Along these lines, two strategies were evaluated for LA production in our consortium ${ }^{140}$, wherein pre-treatment of $12.5 \%$ SCB loading, Cellic CTec2 enzyme and thermophilic Bacillus coagulans NCIM 5648 were used. In first strategy, when Cellic CTec2 was dosed at $30 \mathrm{FPU} / \mathrm{g}$ of pre-treated SCB, it hydrolysed $75.8 \%$ cellulose and $88.6 \%$ xylan in $24 \mathrm{~h}$. However, when enzyme loading was changed to $25 \mathrm{mg}$ protein/g glucan in the second case, it hydrolysed $72.3 \%$ and $68 \%$ cellulose and xylan respectively. Valorisation of glucose rich filtrates obtained from strategy 1 and 2 using two different media resulted in 50.4 $\mathrm{g} / \mathrm{L}$ and $51.2 \mathrm{~g} / \mathrm{L}$ of LA production from 54.7 to $62.7 \mathrm{~g} / \mathrm{L}$ of glucose respectively. Despite opting for two alternative strategies during high solids SHF, around $50 \mathrm{~g} / \mathrm{L}$ of an optically pure LA production was achieved within a short duration of 45 $54 \mathrm{~h}$ from SCB hydrolysate.

In continuation to above work in our consortium, a comparative study of four pre-treatments -alkali, acid-alkali, alkali-acid and $\mathrm{HC}$ in presence of alkali were conducted for SCB and their impact was evaluated based on sugar released from pretreated SCB after enzymatic hydrolysis and subsequent LA production in a separate fermenter (SHF) by B.coagulans NCIM 5648 ( 141 manuscript under review). The material balance from $100 \mathrm{~g}$ of untreated SCB to LA for alkali (A), acid-alkali (B), alkaliacid (C) and $\mathrm{HC}$ with alkali (D) pre-treatment routes are shown in Figure 7. After pre-treatment of SCB, $59 \mathrm{~g}, 32.4 \mathrm{~g}, 31.2 \mathrm{~g}$ and $62 \mathrm{~g}$ of pre -treated SCB were obtained for cases (A) through to (D) respectively. $17.5 \%(\mathrm{w} / \mathrm{v})$ pre-treated SCB loading was used for enzymatic hydrolysis using Cellic CTec2 enzyme. Enzyme hydrolysed SCB medium was used for LA fermentation using $B$. coagulans. Unlike most of the Bacillus strains reported earlier such as B.coagulans GKN316 and B. coagulans NL01 ${ }^{142}$, B.coagulans NCIM 5648 was unable to valorise xylose to LA. 
Table 8: Summary of lactic acid production from SCB

\begin{tabular}{|c|c|c|c|c|c|c|c|}
\hline Microorganism & Pre-treatment & $\begin{array}{l}\text { Detoxification } \\
\text { method }\end{array}$ & $\begin{array}{l}\text { Fermentation } \\
\text { mode }\end{array}$ & $\begin{array}{l}\text { Titer } \\
\text { (g/L) }\end{array}$ & Yield (g/g) & $\begin{array}{l}\text { Productivity } \\
\text { (g/L/h) }\end{array}$ & Reference \\
\hline Bacillus sp. 36D1 & Acid & $\begin{array}{l}\text { Acid hydrolysate } \\
\text { treated with lime }\end{array}$ & Batch SSF & 35 & - & 0.24 & Patel et al., $2005^{137}$ \\
\hline $\begin{array}{l}\text { Lactobacillus delbreuckii } \\
\text { mutant Uc-3 }\end{array}$ & Steam-alkali & - & Batch SSF & 67.0 & 0.83 & 0.93 & Adsul et al., $2007^{138}$ \\
\hline Lactobacillus casei & Acid-solvent & $\begin{array}{l}\text { Solid fraction } \\
\text { water wash }\end{array}$ & Batch & 25.7 & 1.00 & 0.27 & Jonglertjunya et al., $2014^{143}$ \\
\hline Bacillus sp. P38 & Acid-alkali & $\begin{array}{l}\text { Solid fraction } \\
\text { water wash }\end{array}$ & Fed-batch & 185.0 & 0.99 & 1.93 & Peng et al., $2014^{144}$ \\
\hline Bacillus coagulans & $\begin{array}{l}\text { Acid-steam } \\
\text { explosion }\end{array}$ & $\begin{array}{l}\text { Solid fraction } \\
\text { water wash }\end{array}$ & Batch SSF & 70.4 & 0.90 & 1.14 & van der Pol et al., $2016^{139}$ \\
\hline Lactobacillus pentosus & Acid-steam & $\begin{array}{l}\text { Solid fraction } \\
\text { water wash }\end{array}$ & Fed-batch SSF & 72.7 & 0.61 & 1.01 & Unrean, $2018^{145}$ \\
\hline Bacillus coagulans & Acid & $\begin{array}{l}\text { Acid hydrolysate } \mathrm{pH} \\
\text { adjustment }\end{array}$ & Batch & 55.9 & 0.87 & 1.7 & de Oliveira et al., $2019^{131}$ \\
\hline Lactobacillus pentosus & Acid-alkali & $\begin{array}{l}\text { Acid hydrolysate } \mathrm{pH} \\
\text { adjustment }\end{array}$ & Batch & 65.0 & 0.93 & 1.01 & Wischral et al., $2019^{146}$ \\
\hline Lactobacillus pentosus & Acid & $\begin{array}{l}\text { Acid hydrolysate } \mathrm{pH} \\
\text { adjustment followed } \\
\text { by filtration }\end{array}$ & Batch & 55.4 & 0.72 & 0.43 & González-Leos et al., $2019^{147}$ \\
\hline \multirow{4}{*}{ Bacillus coagulans } & Alkali & \multirow{4}{*}{$\begin{array}{l}\text { Solid fraction } \\
\text { water wash }\end{array}$} & \multirow{4}{*}{ Batch } & 68.7 & 0.92 & 2.86 & \multirow{4}{*}{$\begin{array}{l}\text { Nalawade et al., 2020b } \\
\text { (Manuscript under review) }\end{array}$} \\
\hline & Acid-alkali & & & 66.9 & 0.88 & 2.79 & \\
\hline & Alkali-acid & & & 71.8 & 0.90 & 2.99 & \\
\hline & $\begin{array}{l}\text { Cavitation with } \\
\text { alkali }\end{array}$ & & & 62.5 & 0.92 & 2.60 & \\
\hline
\end{tabular}




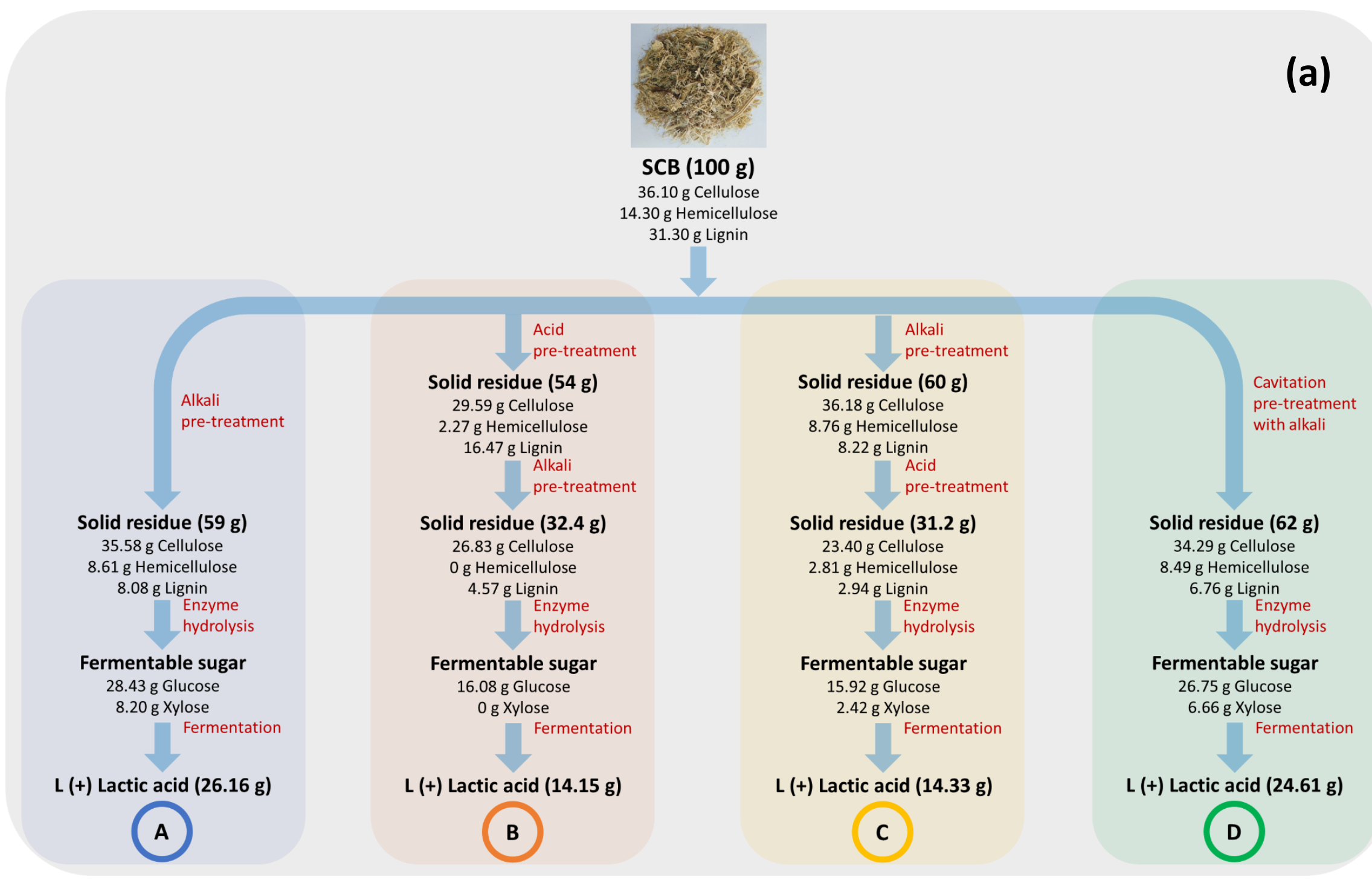




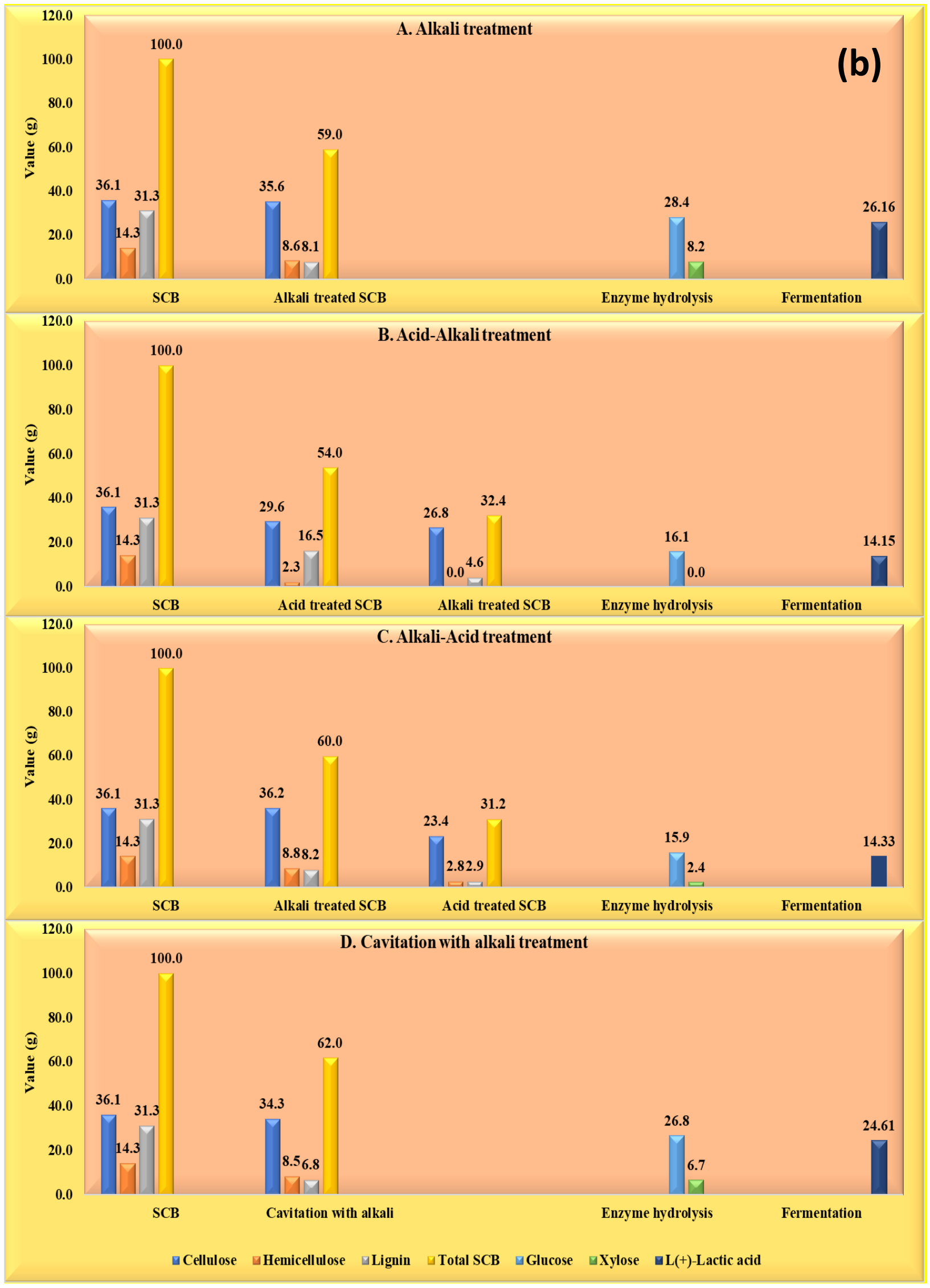

Figure 7: Mass balance of LA production by B. coagulans using SCB pre-treated with different methods, (a) SCB to LA mass balance in numbers and (b) SCB to LA mass balance in bar charts 
For the alkali pre-treatment (A), recovery of $35.58 \mathrm{~g}$ cellulose, $8.6 \mathrm{~g}$ hemicellulose, and $8.1 \mathrm{~g}$ lignin in $59 \mathrm{~g}$ alkali treated SCB was achieved from $100 \mathrm{~g}$ untreated SCB. For the enzyme hydrolysis, $17.5 \mathrm{~g}$ of alkali treated SCB $(17.5 \% \mathrm{w} / \mathrm{v})$ was used. This resulted in $84.3 \mathrm{~g} / \mathrm{L}$ of glucose release with hydrolysis efficiency of $72 \%$. The enzyme hydrolysate was used for lactic acid fermentation using $B$. coagulans NCIM 5648. L(+) LA titer, productivity and yield of $68.7 \mathrm{~g} / \mathrm{L}, 2.86 \mathrm{~g} / \mathrm{L} / \mathrm{h}$ and $0.92 \mathrm{~g} / \mathrm{g}$ was achieved respectively. From this route, $28.43 \mathrm{~g}$ of glucose was released during hydrolysis and $26.16 \mathrm{~g}$ of $\mathrm{L}(+) \mathrm{LA}$ was produced. For the sequential alkali-acid pre-treatment $(C), 23.4 \mathrm{~g}$ cellulose recovery in $31.2 \mathrm{~g}$ of alkali-acid treated SCB was obtained from $100 \mathrm{~g}$ untreated SCB. As mentioned earlier in (A), $17.5 \mathrm{~g}$ of alkali-acid treated SCB was used for enzyme hydrolysis. The highest sugar release of $89.3 \mathrm{~g} / \mathrm{L}$ was achieved for the alkaliacid pre-treated SCB. After fermentation of enzyme hydrolysate, $\mathrm{L}(+) \mathrm{LA}$ titer, productivity and yield of $71.8 \mathrm{~g} / \mathrm{L}, 2.99$ $\mathrm{g} / \mathrm{L} / \mathrm{h}$ and $0.90 \mathrm{~g} / \mathrm{g}$ was achieved respectively. This corresponded to $14.33 \mathrm{~g} \mathrm{~L}(+) \mathrm{LA}$. With cavitation in presence of alkali (D), L(+) LA titer: $62.5 \mathrm{~g} / \mathrm{L}$; productivity: $2.60 \mathrm{~g} / \mathrm{L} / \mathrm{h}$ and yield: $0.92 \mathrm{~g} / \mathrm{g}$ was achieved. While (D) was similar to (A), sequential acid-alkali pre-treatment (B) was similar to (C). Considering the overall approach (Figure 7 \& Table 8), alkali pre-treatment was found to be the best method for an enhanced L(+) LA yield. The product yield achieved was over 80 $\%$ higher in comparison to the sequential pre-treatment. The material balance of multiple routes clearly shows that substantial loss of the materials during any pre-treatment step may result in the lower economic efficiency of the overall process.

\section{Summary and path forward}

This brief review outlines the need and the potential of valorisation of waste biomass streams produced by sugar industries (in India) in line with the sentence attributed to Mahatma Gandhi "Waste is a resource in the wrong place"148. Current situation of large national stocks of sugar and overall price trends of sugar in world markets are driving down prices of sugar in India. Therefore, transforming so called waste biomass streams of sugar mills to higher value products is needed more than ever. The crux of transforming the waste biomass streams into resource is to ensure that the cost of pretreating these biomass streams (for making them amenable for further value addition) and the cost of extracting value added products from pre-treated waste streams to be lower than the potential revenue generated by the recovered products. An attempt is made here to recap the discussion and provide specific recommendations based on the earlier discussion.

$\mathrm{SCB}$, the predominant solid waste generated during sugarcane processing is a complex lignocellulosic biomass containing valuable components in cellulose and hemicellulose (interlinked to lignin) which requires significant pre-treatment. Pre-treatment of SCB is broadly grouped into two classes: first is for opening up the lignocellulosic matrix and enhancing the bioavailability of SCB. This is mainly used for recovering biogas
- biomethane from SCB. $\mathrm{HC}$ is the most economical and recommended option for this class of pre-treatment ${ }^{41}$. The second class of pre-treatment is focussed on enhancing the enzymatic saccharification yield from SCB ( $C 5$ and $\mathrm{C} 6$ sugars). Mild acid hydrolysis in the presence of steam is the recommended option when $\mathrm{C} 5$ rich hydrolysate is the desired entity ${ }^{57,58}$. Enzymatic hydrolysis of the obtained cellulignin or subjecting it to alkali hydrolysis prior to enzymatic hydrolysis will yield a cellulose rich residue.

In an integrated biorefinery approach, $\mathrm{C} 6$ sugar (glucose) from SCB can be utilized for LA or ethanol production and C5 sugar (xylose) in hydrolysate may be utilized for SA or xylitol production or biogas production using anaerobic digestion. Integrated approach for the co-production of ethanol (from C6) and xylitol (from C5), from SCB is a promising starting point ${ }^{94}$, however further investigative efforts are required to progress further for realising these approaches at industrial scale.

It is necessary to make use of microorganism(s), which can metabolize C6 as well as C5 sugars to maximize the bioconversion of lignocellulosic sugars ${ }^{87}$. Unlike glucose, $x y l o s e$ valorisation through biochemical route is largely ignored, as most of the industrial microbes lack efficient metabolic pathway for its assimilation. Further, those microbial strains which can assimilate xylose suffer a major setback due to preference for glucose as carbon substrate over xylose. This suppresses xylose utilization during co-fermentation due to carbon catabolite repression (CCR) 97, 149. Hence, more attention needs to be paid to the rewiring of metabolic networks of microbial strains to metabolize multiple carbon sources, especially glucose and xylose, from the feedstock which will be essential for de-risking the commercial viability of the bioprocesses 150,151 . In the last two decades, Efforts on xylose valorisation have intensified ${ }^{152}$. To improve the efficacy of xylose-based fermentation, efficient xylose-utilizing as well as non-xylose/inefficient xylose-utilizing strains have been engineered to expand the available substrate range, enable rapid assimilation of xylose and eliminate $C C R$ for manufacturing fuels and chemicals from LCB-based feedstock $123,153,154$. Despite advances in metabolic engineering and synthetic biology tools, xylose is still an inferior carbon source in comparison to glucose and more efforts are required to design efficient microbial cell factories for xylose-based production. Besides, development of robust strains with high level tolerance against inhibitor released during pre-treatment and end product can result in high yield product which will eventually benefit the overall process economics ${ }^{151,152}$.

Hydrolysis and fermentation processes need to be intensified for enhancing productivity of SCB based biorefinery. The optimal conditions for hydrolysis and fermentation may be different and will vary for enzyme complex used for hydrolysis and microbes used for fermentative production of desired product. Therefore, to achieve better combined productivity (hydrolysis \& fermentation), selection of SHF vs SSF is critical. For a specific case of LA production, SHF is recommended over SSF for better productivity 140,141 . 


\section{ARTICLE}

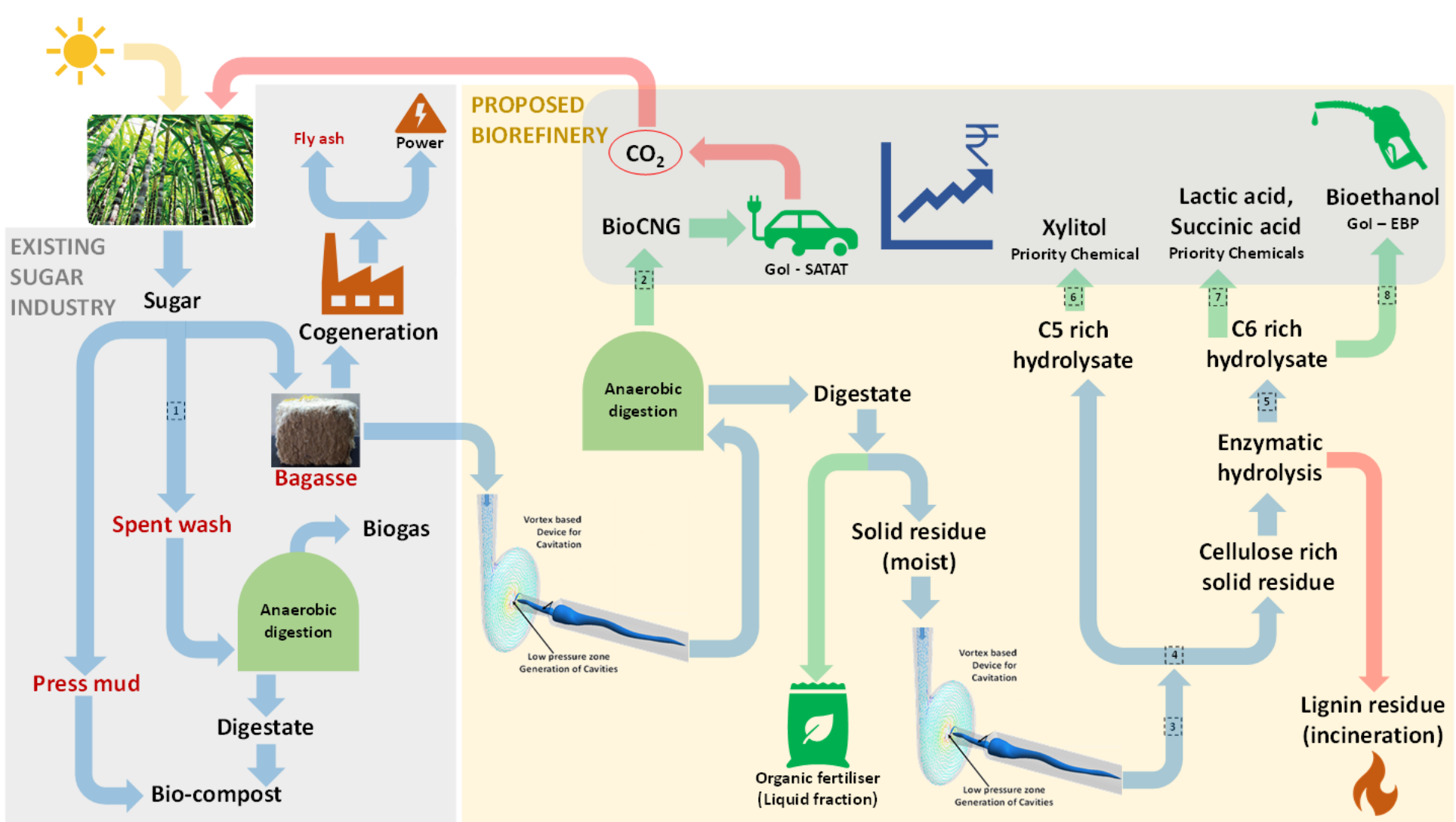

Figure 8: Current status and path forward. Numbers in dotted squares denote, 1 - molasses fermentation to ethanol producing spent wash as a waste stream, 2 - partial conversion of organic carbon to biogas and upgradation to bioCNG, 3 - mild acid hydrolysis, 4 - filtration and concentration to separate $\mathrm{C} 5$ hydrolysate from solid residue, 5 - filtration and concentration of $\mathrm{C} 6$ sugars and enzyme recovery, 6-C5 fermentation to xylitol, 7-C6 fermentation to lactic or succinic acid and 8-Bioethanol fermentation 
Current state of the art processes for transforming SCB to the value added products discussed here are still not yet economically feasible 92-94, 96, 124, 125. Major drivers for the deployment of biorefineries are sustainable \& renewable energy supply, inclusive economic growth to save foreign exchange, less dependency on imported crude petroleum, low carbon footprint and green environment. Despite having high potential, establishment of a biorefinery faces the following challenges. Firstly, round the year availability of lignocellulosic feedstock at low price is a major concern for biorefineries. It is crucial to establish a proper mechanism for collection, transportation and handling of biomass feedstock. Secondly, $2 \mathrm{G}$ biorefinery investments are capital-intensive, involve large risks, and takes a long time to become market ready. Lastly, as discussed previously, pre-treatment and enzymatic hydrolysis can account for up to $40 \%$ of the total operational costs. Regarding the sugar industry in India, as far as the feedstock and supply-chain is concerned, the existing sugar mills have a wellestablished supply chain for sugarcane and hence readily available SCB on site. A typical sugar plant consists of a sugar unit, an ethanol production unit, a cogeneration plant (steam and power) and an anaerobic digestion unit (when a distillery is attached). These units facilitate the use of surplus steam, electricity and water on site. Typical equipment and process machinery required for expanding the plant are not different to those required for setting up biorefineries. These include fermenters, distillation columns, evaporation plant, anaerobic digesters, etc which can be used to setup biorefinery facilities. Saccharification modules required for the production of $\mathrm{C5}$ or C6 sugars from polysaccharides may be the only new addition that is currently alien to sugar industries. Such a project can be a 'bolt-on' project which will be much cheaper than a Greenfield project. We believe that $A D$ centric biorefinery may overcome some of the limitations of the state of the art and make the valorisation techno-economically viable. $A D$ is an accepted technology in the sugar industry as they are used to operating digesters for processing spent wash from associated distilleries. $A D$ is a robust technology and can handle fluctuations in feed quality and quantity. It hosts a consortium of microbes working in synergy and therefore can handle wider range of $\mathrm{pH}$ and temperature. The capex requirements of $A D$ are also one of the lowest among the competing technology platforms. The disadvantages of $A D$ are the underlying transformation processes that are usually slow as they require large residence time - leading to larger digester volumes. It also offers limited control over substrate fraction selectivity. HC based pretreatment can be used to intensify $A D$ operation. It has been shown that $\mathrm{HC}$ based pre-treatment improves rate as well as yield of biogas generation. One of the promising paths forward that we envisage is, the use of AD not only as a bioprocess step for energy recovery but also as 'pre-treatment'. In addition to recovering energy in the form of biogas - biomethane, it will also open up the lignocellulosic matrix of biomass (SCB). In the envisaged biorefinery, $A D$ is used for only partially converting the organic carbon in the feed to biogas/biomethane. The digestate is processed further by separating the solid and liquid fractions, where the former will be subjected to pre-treatment for recovering $\mathrm{C} 5$ and $\mathrm{C} 6$ sugars and the latter can be sold as fertiliser. $\mathrm{C} 5$ and $\mathrm{C} 6$ sugars produced from digestate can be used for generating high value products such as alcohols (ethanol, xylitol) and acids (LA, SA). It has to be ensured that the high value products produced from the 'digestate' should be of intended purity determined by the industry (e.g, 80-90\% purity required for food grade lactic acid and $>90 \%$ for pharmaceutical grade ${ }^{155}$ ) and free from contaminants. This proposed biorefinery is shown in Figure 8. The intended idea of using $A D$ for partial conversion offers several advantages like smaller digester due to shorter residence time (required for partial conversion) and an inexpensive way to distort the lignocellulosic matrix for further bioprocessing. This has a potential of substantially reducing the cost of conversion to sugars and thereby improving the overall economic viability. This approach may eliminate the need for harsh thermochemical treatments or expensive enzymatic treatment.

Further research, specifically on identifying optimal HC based pre-treatment suitable for partial conversion of organic carbon to biogas in $A D$, further cavitation based pre-treatment of digestate to make it amenable for extracting sugars and subsequent fermentation of sugars to desired products (alcohols and acids) is needed to realise the proposed biorefinery. We hope that this review and the proposed biorefinery will stimulate potential translation of ongoing research to practice in near future.

\section{Declaration of interests}

One of the authors, Professor Vivek Ranade is a co-founder and Director of Vivira Process Technologies Pvt. Ltd., India, which commercially offers hydrodynamic cavitation devices.

\section{Acknowledgements}

This work was supported by Innovate UK, Newton Fund, BBSRC UK and Department of Biotechnology, Government of India (vWa Project, Grant BB/S011951/1). 


\section{Appendix 1}

Methane: $\frac{m^{3} \mathrm{CH}_{4}}{\mathrm{kgVS}}=\frac{22.4 \times\left(\frac{a}{2}+\frac{b}{8}-\frac{c}{4}-\frac{3 d}{8}-\frac{e}{4}\right)}{12 a+b+16 c+14 d+32 e}$

where biomass is represented with chemical formula $C_{a} H_{b} O_{c} N_{d} S_{e}$

Stoichiometric equation for different products from glucose:

Ethanol: $\quad \mathrm{C}_{6} \mathrm{H}_{12} \mathrm{O}_{6} \rightarrow 2 \mathrm{C}_{2} \mathrm{H}_{6} \mathrm{O}+2 \mathrm{CO}_{2}$

Succinic acid: $\mathrm{C}_{6} \mathrm{H}_{12} \mathrm{O}_{6}+\frac{6}{7} \mathrm{CO}_{2} \rightarrow \frac{12}{7} \mathrm{C}_{4} \mathrm{H}_{6} \mathrm{O}_{4}+\frac{6}{7} \mathrm{H}_{2} \mathrm{O}$

Lactic acid: $\mathrm{C}_{6} \mathrm{H}_{12} \mathrm{O}_{6} \rightarrow 2 \mathrm{C}_{3} \mathrm{H}_{6} \mathrm{O}_{3}$

Xylitol:

$$
\mathrm{C}_{6} \mathrm{H}_{12} \mathrm{O}_{6}+\frac{6}{11} \mathrm{H}_{2} \mathrm{O} \rightarrow \frac{12}{11} \mathrm{C}_{5} \mathrm{H}_{11} \mathrm{O}_{5}+\frac{6}{11} \mathrm{CO}_{2}
$$

\section{Stoichiometric equation for different products from xylose:}

Ethanol: $\quad \mathrm{C}_{5} \mathrm{H}_{10} \mathrm{O}_{5} \rightarrow \frac{5}{3} \mathrm{C}_{2} \mathrm{H}_{6} \mathrm{O}+\frac{5}{3} \mathrm{CO}_{2}$

Succinic acid: $\mathrm{C}_{5} \mathrm{H}_{10} \mathrm{O}_{5}+\frac{5}{7} \mathrm{CO}_{2} \rightarrow \frac{10}{7} \mathrm{C}_{4} \mathrm{H}_{6} \mathrm{O}_{4}+\frac{5}{7} \mathrm{H}_{2} \mathrm{O}$

Lactic acid: $\mathrm{C}_{5} \mathrm{H}_{10} \mathrm{O}_{5} \rightarrow \frac{5}{3} \mathrm{C}_{3} \mathrm{H}_{6} \mathrm{O}_{3}$

Xylitol: $\quad \mathrm{C}_{5} \mathrm{H}_{10} \mathrm{O}_{5}+\frac{5}{11} \mathrm{H}_{2} \mathrm{O} \rightarrow \frac{10}{11} \mathrm{C}_{5} \mathrm{H}_{11} \mathrm{O}_{5}+\frac{5}{11} \mathrm{CO}_{2}$

\section{References}

1.

National Federation of Co-operative Sugar Factories Limited, Cooperative sugar, National Federation of Cooperative Sugar Factories Ltd., New Delhi, 2019.

2. M. Meghana and Y. Shastri, Bioresour. Technol., 2020, 303, 122929.

3. S. Solomon, Sugar Tech, 2011, 13, 255-265

4. P. A. Ochoa George, J. J. C. Eras, A. S. Gutierrez, L. Hens and C. Vandecasteele, Waste and Biomass Valorization, 2010, 1, 407-413.

5. J. M. Hernández-Salas, M. S. Villa-Ramírez, J. S. VelozRendón, K. N. Rivera-Hernández, R. A. González-César, M. A. Plascencia-Espinosa and S. R. Trejo-Estrada, Bioresour. Technol., 2009, 100, 1238-1245.

6. A. Pandey, C. R. Soccol, P. Nigam and V. T. Soccol, Bioresour. Technol., 2000, 74, 69-80.

7. M. R. Trejo-Hernández, A. Ortiz, A. I. Okoh, D. Morales and R. Quintero, Chemosphere, 2007, 68, 848-855.

8. P. Purohit and S. Dhar, 2015

9. N. K. Bhardwaj, D. Kaur, S. Chaudhry, M. Sharma and S. Arya, Journal of Cleaner Production, 2019, 217, 225-233.

$10 . \quad$ H. C. J. Franco, M. T. B. Pimenta, J. L. N. Carvalho, P. S. G. Magalhães, C. E. V. Rossell, O. A. Braunbeck, A. C. Vitti, O. T. Kölln and J. Rossi Neto, Scientia Agricola, 2013, 70, 305312.

11. P. Singh, A. Suman, P. Tiwari, N. Arya, A. Gaur and A. K Shrivastava, World J. Microbiol. Biotechnol., 2008, 24, 667673.

12. P. C. Abhilash and N. Singh, Bioresour. Technol., 2008, 99, 8961-8966.
13. S. Ezhumalai and V. Thangavelu, Bioresources, 2010, 5 , 1879-1894.

14. S. Ingle, P. Ashtavinayak, D. Amol and P. Sanjay, Journal of Environmental Chemical Engineering, 2017, 5, 2861-2868.

15. S. Velmurugan and N. Partha, Journal of Indian Chemical Engineer, 2006, 48, 160-163.

16. K. Umamaheswaran and V. S. Batra, Fuel, 2008, 87, 628638.

17. Ministry of New and Renewable Energy - Government of India, Programme/Scheme wise Physical Progress in 202021 \& Cumulative upto June, 2020, https://mnre.gov.in/theministry/physical-progress, (accessed $04 \mathrm{Sep}$, 2020).

18. M. R. Islam, H. Haniu, M. N. Islam and M. S. Uddin, Journal of Thermal Science and Technology, 2010, 5, 11-23.

19. M. R. L. V. Leal, M. V. Galdos, F. V. Scarpare, J. E. A. Seabra, A. Walter and C. O. F. Oliveira, Biomass Bioenergy, 2013, 53, 11-19.

20. E. V. Gonçalves, F. L. Seixas, L. R. de Souza Scandiuzzi Santana, M. H. N. O. Scaliante and M. L. Gimenes, The Canadian Journal of Chemical Engineering, 2017, 95, 12691279. R. Memon, A. A. Malik and S. Hussain, Technical Journal, 2017, 22.

22. A. Shukla and S. Y. Kumar, Int. J. Appl. Eng. Res, 2017, 12 14739-14745.

23. A. K. Varma and P. Mondal, Industrial Crops and Products, 2017, 95, 704-717.

24. P. Ghorbannezhad, M. D. Firouzabadi, A. Ghasemian, P. J. de Wild and H. J. Heeres, J. Anal. Appl. Pyrolysis, 2018, 131, 1-8.

25. S. Kanwal, N. Chaudhry, S. Munir and H. Sana, Waste Manag, 2019, 88, 280-290.

26. K. Manatura, Case Studies in Thermal Engineering, 2020, 19, 100623

27. L. Venkateswar Rao, J. K. Goli, J. Gentela and S. Koti, Bioresour. Technol., 2016, 213, 299-310.

28. T. L. Bezerra and A. J. Ragauskas, Biofuels, Bioproducts and Biorefining, 2016, 10, 634-647.

29. S. Farzad, M. A. Mandegari, M. Guo, K. F. Haigh, N. Shah and J. F. Görgens, Biotechnology for Biofuels, 2017, 10, 87.

30. B. Yang and C. E. Wyman, Biofuels, Bioproducts and Biorefining, 2008, 2, 26-40.

31. A. S. A. da Silva, H. Inoue, T. Endo, S. Yano and E. P. S. Bon, Bioresour. Technol., 2010, 101, 7402-7409.

32. S. Park, J. O. Baker, M. E. Himmel, P. A. Parilla and D. K. Johnson, Biotechnology for Biofuels, 2010, 3, 10.

33. Z. Miao, T. E. Grift, A. C. Hansen and K. C. Ting, Industrial Crops and Products, 2011, 33, 504-513.

34. R. d. R. O. d. Barros, R. d. S. Paredes, T. Endo, E. P. d. S. Bon and S.-H. Lee, Bioresour. Technol., 2013, 136, 288-294.

35. B. Buaban, H. Inoue, S. Yano, S. Tanapongpipat, V Ruanglek, V. Champreda, R. Pichyangkura, S. Rengpipat and L. Eurwilaichitr, J. Biosci. Bioeng., 2010, 110, 18-25.

36. Y. Sun and J. Cheng, Bioresour. Technol., 2002, 83, 1-11.

37. A. K. Kivaisi and S. Eliapenda, Renewable Energy, 1994, 5, 791-795.

38. A. F. Leite, L. Janke, H. Harms, J. W. Zang, W. Fonseca-Zang, W. Stinner and M. Nikolausz, Energ. Fuels., 2015, 29, 40224029.

39. S. C. Rabelo, H. Carrere, R. Maciel Filho and A. C. Costa, Bioresour. Technol., 2011, 102, 7887-7895. 
40.

A. G. Costa, G. C. Pinheiro, F. G. C. Pinheiro, A. B. Dos Santos, S. T. Santaella and R. C. Leitão, Chem. Eng. J., 2014, 248, 363-372.

41. S. Nagarajan and V. V. Ranade, Ind. Eng. Chem. Res., 2019, 58, 15975-15988.

42. J. de Cassia Pereira, N. Paganini Marques, A. Rodrigues, T. Brito de Oliveira, M. Boscolo, R. da Silva, E. Gomes and D. A. Bocchini Martins, J. Appl. Microbiol., 2015, 118, 928-939.

43. D. Deswal, R. Gupta, P. Nandal and R. C. Kuhad, Carbohydr. Polym., 2014, 99, 264-269.

44. A. d. S. Machado and A. Ferraz, Bioresour. Technol., 2017, 225, 17-22.

45. C. Carrasco, H. M. Baudel, J. Sendelius, T. Modig, C. Roslander, M. Galbe, B. Hahn-Hägerdal, G. Zacchi and G. Lidén, Enzyme Microb. Technol., 2010, 46, 64-73.

46.

G. J. M. Rocha, L. P. Andrade, C. Martín, G. T. Araujo, V. E. Mouchrek Filho and A. A. S. Curvelo, Industrial Crops and Products, 2020, 147, 112227.

47. US9862980B2, 2018.

48. A. F. A. Carvalho, W. F. Marcondes, P. de Oliva Neto, G. M. Pastore, J. N. Saddler and V. Arantes, Bioresour. Technol., 2018, 250, 221-229.

49. P. V. Neves, A. P. Pitarelo and L. P. Ramos, Bioresour. Technol., 2016, 208, 184-194.

50. T. A. L. Silva, H. D. Z. Zamora, L. H. R. Varão, N. S. Prado, M. A. Baffi and D. Pasquini, Waste and Biomass Valorization, 2018, 9, 2191-2201.

51. P. Silva Ortiz and S. de Oliveira, Energy, 2014, 76, 130-138.

52. S. Nagarajan and V. V. Ranade, Bioresource Technology Reports, 2020, DOI: https://doi.org/10.1016/j.biteb.2020.100480, 100480.

53. K. Nakashima, Y. Ebi, N. Shibasaki-Kitakawa, H. Soyama and T. Yonemoto, Industrial \& Engineering Chemistry Research, 2016, 55, 1866-1871. US9422952B2, 2016. M. Langone, M. Soldano, C. Fabbri, F. Pirozzi and G. Andreottola, Appl. Biochem. Biotechnol., 2018, 184, 12001218.

M. Zieliński, P. Rusanowska, A. Krzywik, M. Dudek, A Nowicka and M. Dębowski, Energies, 2019, 12, 525.

S. Pal, S. Joy, P. Kumbhar, K. D. Trimukhe, R. Gupta, R. C. Kuhad, A. J. Varma and S. Padmanabhan, Biomass Conversion and Biorefinery, 2017, 7, 179-189.

58. WO2014203271A2, 2014.

59. M. H. L. Silveira, A. K. Chandel, B. A. Vanelli, K. S. Sacilotto and E. B. Cardoso, Bioresource Technology Reports, 2018, 3, 138-146.

60. M. E. Vallejos, M. D. Zambon, M. C. Area and A. A. d. S. Curvelo, Industrial Crops and Products, 2015, 65, 349-353.

61. L. Mesa, E. González, C. Cara, M. González, E. Castro and S. I. Mussatto, Chem. Eng. J., 2011, 168, 1157-1162.

62. A. S. A. da Silva, S.-H. Lee, T. Endo and E. P. S. Bon, Bioresour. Technol., 2011, 102, 10505-10509.

63. T. Mokomele, L. da Costa Sousa, V. Balan, E. Van Rensburg, B. E. Dale and J. F. Görgens, Biotechnology for biofuels, 2018, 11, 127.

64. T. Benazzi, S. Calgaroto, V. Astolfi, C. Dalla Rosa, J. V. Oliveira and M. A. Mazutti, Enzyme Microb. Technol., 2013, 52, 247-250.

65. M. J. Madison, G. Coward-Kelly, C. Liang, M. N. Karim, M. Falls and M. T. Holtzapple, Biomass Bioenergy, 2017, 98 135-141.
66. O. Jafari and H. Zilouei, Bioresour. Technol., 2016, 214, 670678.

67. K. Kapoor, N. Garg, R. K. Diwan, L. Varshney and A. K. Tyagi, Radiat. Phys. Chem., 2017, 141, 190-195.

68. T. Zhang and M.-J. Zhu, Bioresour. Technol., 2016, 214, 769777.

69. M. Ambye-Jensen, R. Balzarotti, S. T. Thomsen, C. Fonseca and Z. Kádár, Biotechnology for Biofuels, 2018, 11, 336.

70. P. J. Meynell, Methane: Planning a Digester, Schocken Books, New York, 1976.

S. Mittal, E. O. Ahlgren and P. R. Shukla, Energy Policy, 2018, 112, 361-370.

Ministry of Petroleum Natural Gas Government of India, Journal, 2018, 2019.

73. Indian Oil Corporation Limited, Bharat Petroleum Corporation Limited and H. P. C. Limited, Journal, 2018.

H. Katuwal and A. K. Bohara, Renewable and Sustainable Energy Reviews, 2009, 13, 2668-2674.

75. L. Janke, A. Leite, M. Nikolausz, T. Schmidt, J. Liebetrau, M. Nelles and W. Stinner, Int. J. Mol. Sci., 2015, 16, 20685.

76. S. Sajad Hashemi, K. Karimi and A. Majid Karimi, Fuel, 2019, 248, 196-204.

77. A. M. Mustafa, H. Li, A. A. Radwan, K. Sheng and X. Chen, Bioresour. Technol., 2018, 259, 54-60.

78. M. Badshah, D. M. Lam, J. Liu and B. Mattiasson, Bioresour. Technol., 2012, 114, 262-269.

79. F. R. Ribeiro, F. Passos, L. V. A. Gurgel, B. E. L. Baêta and S. F. de Aquino, Sci. Total Environ., 2017, 584-585, 11081113.

80. L. Janke, A. F. Leite, M. Nikolausz, C. M. Radetski, M. Nelles and W. Stinner, Waste Management, 2016, 48, 199-208.

81. M. Hassan, W. Ding, M. Umar and G. Rasool, Bioresource Technology, 2017, 230, 24-32.

82. N. Aramrueang, J. Rapport and R. Zhang, Biosystems Engineering, 2016, 147, 174-182.

83. P. V. Rao, S. S. Baral, R. Dey and S. Mutnuri, Renewable and Sustainable Energy Reviews, 2010, 14, 2086-2094.

84. C. Sawatdeenarunat, K. C. Surendra, D. Takara, H. Oechsner and S. K. Khanal, Bioresour. Technol., 2015, 178, 178-186.

85. A. F. Hernández-Pérez, I. A. L. Costa, D. D. V. Silva, K. J. Dussán, T. R. Villela, E. V. Canettieri, J. A. Carvalho, T. G. Soares Neto and M. G. A. Felipe, Bioresour. Technol., 2016, 200, 1085-1088.

86. A. W. Bhutto, K. Harijan, K. Qureshi, A. A. Bazmi and A. Bahadori, Journal of Cleaner Production, 2015, 95, 184193.

87. L. Canilha, A. K. Chandel, T. S. S. Milessi, F. A. F. Antunes, W. L. C. Freitas, M. G. A. Felipe and S. S. da Silva, J. Biomed. Biotechnol., 2012, 2012.

88. J. T. Cunha, P. O. Soares, A. Romaní, J. M. Thevelein and L. Domingues, Biotechnology for Biofuels, 2019, 12, 20.

89. R. E. Hector, J. A. Mertens, M. J. Bowman, N. N. Nichols, M. A. Cotta and S. R. Hughes, Yeast, 2011, 28, 645-660.

90. A. de Araujo Guilherme, P. V. F. Dantas, C. E. d. A. Padilha, E. S. dos Santos and G. R. de Macedo, J. Environ. Manage., 2019, 234, 44-51.

Y. Liu, J. X. Xu, Y. Zhang, M. He, C. Liang, Z. Yuan and J. Xie, BioResources, 2016, 11, 2548-2556.

92. O. Rosales-Calderon and V. Arantes, Biotechnology for Biofuels, 2019, 12, 240. 
93.

S. Vieira, M. V. Barros, A. C. N. Sydney, C. M. Piekarski, A. C. de Francisco, L. P. d. S. Vandenberghe and E. B. Sydney, Bioresour. Technol., 2020, 299, 122635.

94. A. F. Hernández-Pérez, P. V. de Arruda, L. Sene, S. S. da Silva, A. Kumar Chandel and M. d. G. de Almeida Felipe, Crit. Rev. Biotechnol., 2019, 39, 924-943.

95. D. Dasgupta, D. Ghosh, S. Bandhu and D. K. Adhikari, Microbiol. Res., 2017, 200, 64-72.

96. Y. Xu, P. Chi, M. Bilal and H. Cheng, Appl. Microbiol. Biotechnol., 2019, 103, 5143-5160.

97. A. A. Prabhu, D. J. Thomas, R. Ledesma-Amaro, G. A. Leeke, A. Medina, C. Verheecke-Vaessen, F. Coulon, D. Agrawal and V. Kumar, Microbial Cell Factories, 2020, 19, 121.

98. A. A. Prabhu, E. Bosakornranut, Y. Amraoui, D. Agarwal, F. Coulon, V. Vivekanand, V. K. Thakur and V. Kumar, Biotechnol. Biofuels. (under review), 2020, DOI: 10.21203/rs.3.rs-45506/v1.

99. P. Unrean and N. Ketsub, Industrial Crops and Products, 2018, 123, 238-246.

100. D. D. V. da Silva, P. V. de Arruda, F. M. C. F. Vicente, L. Sene, S. S. da Silva and M. das Graças de Almeida Felipe, Annals of Microbiology, 2015, 65, 687-694.

101. J. F. Castañón-Rodríguez, J. M. Domínguez-González, B. Ortíz-Muñiz, B. Torrestiana-Sanchez, J. A. R. de León and M. G. Aguilar-Uscanga, Eng. Life Sci., 2015, 15, 96-107.

102. A. D. Mountraki, K. R. Koutsospyros, B. B. Mlayah and A. C. Kokossis, Waste and Biomass Valorization, 2017, 8, 22832300.

103. K.-K. Cheng, X.-B. Zhao, J. Zeng, R.-C. Wu, Y.-Z. Xu, D.-H. Liu and J.-A. Zhang, Appl. Microbiol. Biotechnol., 2012, 95, 841850.

104. M. Babaei, K. Rueksomtawin Kildegaard, A. Niaei, M. Hosseini, S. Ebrahimi, S. Sudarsan, I. Angelidaki and I. Borodina, Frontiers in Bioengineering and Biotechnology, 2019, 7, 361.

105. J. Akhtar, A. Idris and R. Abd. Aziz, Appl. Microbiol. Biotechnol., 2014, 98, 987-1000.

106. E. Stylianou, C. Pateraki, D. Ladakis, M. Cruz-Fernández, M. Latorre-Sánchez, C. Coll and A. Koutinas, Biotechnology for Biofuels, 2020, 13, 72.

107. E. R. Borges and N. Pereira, J. Ind. Microbiol. Biotechnol., 2011, 38, 1001-1011.

108. Y.-I. Xi, W.-y. Dai, R. Xu, J.-h. Zhang, K.-q. Chen, M. Jiang, P. Wei and P.-k. Ouyang, Bioprocess Biosystems Eng., 2013, 36, 1779-1785.

109. R. C. L. B. Rodrigues, M. G. A. Felipe, I. C. Roberto and M. Vitolo, Bioprocess Biosystems Eng., 2003, 26, 103-107.

110. W. Carvalho, J. C. Santos, L. Canilha, J. B. Almeida e Silva, M. G. A. Felipe, I. M. Mancilha and S. S. Silva, Process Biochem., 2004, 39, 2135-2141.

111. R. S. Rao, C. P. Jyothi, R. S. Prakasham, P. N. Sarma and L. V. Rao, Bioresour. Technol., 2006, 97, 1974-1978.

112. C.-F. Huang, Y.-F. Jiang, G.-L. Guo and W.-S. Hwang, Bioresour. Technol., 2011, 102, 3322-3329.

113. G. Prakash, A. J. Varma, A. Prabhune, Y. Shouche and M. Rao, Bioresour. Technol., 2011, 102, 3304-3308.

114. M. E. Vallejos, M. Chade, E. B. Mereles, D. I. Bengoechea, J. G. Brizuela, F. E. Felissia and M. C. Area, Industrial Crops and Products, 2016, 91, 161-169.

115. V. P. de Arruda, J. C. dos Santos, R. de Cássia Lacerda Brambilla Rodrigues, D. D. V. da Silva, C. K. Yamakawa, G. J. de Moraes Rocha, J. N. Júnior, J. G. da Cruz Pradella, C. E.
Vaz Rossell and M. das Graças de Almeida Felipe, Journal of Industrial and Engineering Chemistry, 2017, 47, 297-302.

116. P. Chen, S. Tao and P. Zheng, Bioresour. Technol., 2016, 211, 406-413.

117. W. Dessie, F. Xin, W. Zhang, Y. Jiang, H. Wu, J. Ma and M. Jiang, Appl. Microbiol. Biotechnol., 2018, 102, 9893-9910.

118. M. Sauer, D. Porro, D. Mattanovich and P. Branduardi, Trends Biotechnol., 2008, 26, 100-108.

119. E. Cavallo, H. Charreau, P. Cerrutti and M. L. Foresti, FEMS Yeast Res., 2017, 17.

120. H.-H. Liu, X.-J. Ji and H. Huang, Biotechnol. Adv., 2015, 33, 1522-1546.

121. M. Egermeier, H. Russmayer, M. Sauer and H. Marx, Frontiers in Microbiology, 2017, 8, 49.

122. K. L. Ong, C. Li, X. Li, Y. Zhang, J. Xu and C. S. K. Lin, Biochem. Eng. J., 2019, 148, 108-115.

123. A. A. Prabhu, R. Ledesma-Amaro, C. S. K. Lin, F. Coulon, V. K. Thakur and V. Kumar, Biotechnology for Biofuels, 2020, 13, 113 .

124. M. Nieder-Heitmann, K. Haigh, J. Louw and J. F. Görgens, Biofuels, Bioproducts and Biorefining, 2020, 14, 55-77.

125. B. C. Klein, J. F. L. Silva, T. L. Junqueira, S. C. Rabelo, P. V. Arruda, J. L. lenczak, P. E. Mantelatto, J. G. C. Pradella, S. V. Junior and A. Bonomi, Biofuels, Bioproducts and Biorefining, 2017, 11, 1051-1064.

126. J. J. Bozell and G. R. Petersen, Green Chemistry, 2010, 12, 539-554.

127. R. A. Abd Alsaheb, A. Aladdin, N. Z. Othman, R. Abd Malek, O. M. Leng, R. Aziz and H. A. El Enshasy, Journal of Chemical and Pharmaceutical Research, 2015, 7, 729-735.

128. C. Rodrigues, L. P. S. Vandenberghe, A. L. Woiciechowski, J. de Oliveira, L. A. J. Letti and C. R. Soccol, in Current Developments in Biotechnology and Bioengineering, eds. A. Pandey, S. Negi and C. R. Soccol, Elsevier, 2017, DOI: https://doi.org/10.1016/B978-0-444-63662-1.00024-5, pp. 543-556.

129. T. Ghaffar, M. Irshad, Z. Anwar, T. Aqil, Z. Zulifqar, A. Tariq, M. Kamran, N. Ehsan and S. Mehmood, Journal of Radiation Research and Applied Sciences, 2014, 7, 222-229.

130. B. Oonkhanond, W. Jonglertjunya, N. Srimarut, P. Bunpachart, S. Tantinukul, N. Nasongkla and C. Sakdaronnarong, Journal of Environmental Chemical Engineering, 2017, 5, 2533-2541.

131. A. R. de Oliveira, R. Schneider, C. E. Vaz Rossell, R. Maciel Filho and J. Venus, Bioresource Technology Reports, 2019, 6, 26-31.

132. R. P. John, K. M. Nampoothiri and A. Pandey, Appl. Microbiol. Biotechnol., 2007, 74, 524-534.

133. L. J. Jonsson and C. Martin, Bioresour. Technol., 2016, 199, $103-112$.

A. K. Kumar and S. Sharma, Bioresour Bioprocess, 2017, 4, 7.

M. R. Mukasekuru, J. Hu, X. Zhao, F. F. Sun, K. Pascal, H. Ren and J. Zhang, ACS Sustainable Chemistry \& Engineering, 2018, 6, 12787-12796.

136. D. H. Kim, H. M. Park, Y. H. Jung, P. Sukyai and K. H. Kim, Bioresour. Technol., 2019, 284, 391-397.

137. M. A. Patel, M. S. Ou, L. O. Ingram and K. T. Shanmugam, Biotechnology Progress, 2005, 21, 1453-1460.

138. M. G. Adsul, A. J. Varma and D. V. Gokhale, Green Chemistry, 2007, 9, 58-62. 
139. E. C. van der Pol, G. Eggink and R. A. Weusthuis, Biotechnology for Biofuels, 2016, 9, 248.

140. K. Nalawade, P. Baral, S. Patil, A. Pundir, A. K. Kurmi, K. Konde, S. Patil and D. Agrawal, Renewable Energy, 2020, 157, 708-717.

141. K. Nalawade, P. Saikia, S. Behera, K. S. Konde and S. Patil, Biomass conversion and Biorefinery (under review), 2020.

142. T. Jiang, H. Qiao, Z. Zheng, Q. Chu, X. Li, Q. Yong and J. Ouyang, PLoS One, 2016, 11, e0149101.

143. W. Jonglertjunya, N. Srimarut, N. Lukkanakul, C. Sakdaronnarong and N. Nasongkla, Advanced Materials Research, 2014, 931-932, 1597-1601.

144. L. Peng, N. Xie, L. Guo, L. Wang, B. Yu and Y. Ma, PLOS ONE, 2014, 9, e107143.

145. P. Unrean, Industrial Crops and Products, 2018, 111, 660666.

146. D. Wischral, J. M. Arias, L. F. Modesto, D. de França Passos and N. Pereira Jr, Biotechnology Progress, 2019, 35, e2718.

147. A. González-Leos, M. G. Bustos-Vázquez, G. C. RodríguezCastillejos, L. V. Rodríguez-Durán and A. Del Ángel-Del Ángel, Revista Mexicana de Ingeniería Química, 2019, 19, 377-386.

148. D. Schneider and A. Ragossnig, Waste Manage. Res., 2014, 32, 563-564.

149. C. Sievert, L. M. Nieves, L. A. Panyon, T. Loeffler, C. Morris, R. A. Cartwright and X. Wang, Proc Natl Acad Sci U S A, 2017, 114, 7349-7354.

150. F. M. Gírio, F. Carvalheiro, L. C. Duarte and R. Bogel-Łukasik, in D-Xylitol: Fermentative Production, Application and Commercialization, eds. S. S. da Silva and A. K. Chandel, Springer Berlin Heidelberg, Berlin, Heidelberg, 2012, DOI: 10.1007/978-3-642-31887-0_1, pp. 3-37.

151. V. Kumar, P. Binod, R. Sindhu, E. Gnansounou and V. Ahluwalia, Bioresour. Technol., 2018, 269, 443-451.

152. S. Kwak, J. H. Jo, E. J. Yun, Y. S. Jin and J. H. Seo, Biotechnol. Adv., 2019, 37, 271-283.

153. R. G. de Paula, A. C. C. Antonieto, L. F. C. Ribeiro, N. Srivastava, A. O'Donovan, P. K. Mishra, V. K. Gupta and R. N. Silva, Biotechnol. Adv., 2019, 37, 107347.

154. S. Kwak and Y. S. Jin, Microb Cell Fact, 2017, 16, 82.

155. A. Ahmad, F. Banat and H. Taher, Environmental Technology \& Innovation, 2020, 20, 101138. 